\title{
Symbolic Boundary Work in Pentecostalism: Two Pentecostal Churches
}

Las gentes, estiradas, vigilaban sus gestos, pensando en que los otros las observaban con hostilidad.

MANUEl GálVez, Hombres en soledad, Buenos Aires, 1957:140, quoted in ADAMOVSKY 2009: 106 ${ }^{1}$

The previous chapters of this study have painted a general picture of Pentecostalism and its social context in Argentina. It was revealed that the Pentecostal movement mainly attracts Argentina's lower class and it was argued that this appeal to the lower class is related to its proximity to popular culture and religion, while its low appeal to the educated middle class was explained by a mismatch with the representations of the middle class. Nevertheless, Pentecostalism is not exclusively a lower class religion. There also exists a small group of highly educated middle class Argentineans engaged in the movement. Their religious affiliation stands in tension to their middle class representations. The presence of middle class actors in the Pentecostal movement raises a number of questions: how do they deal with the mismatch between their class representations and their religious affiliation? What type of Pentecostalism do they develop?

The present chapter addresses these questions by exploring the cases of two Pentecostal churches: God Is Love (GIL) and Assembly of Christ (AC). Both churches are medium-sized, with around 400 active members, and are situated in middle class neighborhoods of the city of Buenos Aires. Each church attracts its members primarily from one social class. God Is Love is predominantly a lower class congregation, whereas Assembly of Christ recruits its members mainly from the middle class. Aside from their social composition, the case studies of these churches particularly stress their religious style. The religious style of a church includes a variety of characteristics: its symbolic recognition, the way in which its church services are performed, as well as the configuration of its physical infrastructure and organization. The analysis of

1 "People, all stretched out, were mindful of their bodies, thinking that everyone else was looking upon them with hostility" (Manuel Galvez, Hombres en soledad, Buenos Aires, 1957:140, quoted in Adamovsky 2009: 106).

(C) JENS KOEHRSEN, 2016 | DOI 10.1163/9789004310148_008

This is an open access chapter distributed under the terms of the Creative Commons Attribution-

Noncommercial 3.0 Unported (CC-BY-NC 3.0) License. 
these characteristics undertaken in the following sections of this chapter will reveal stark differences in the religious styles of the two churches.

Analyzing the two Pentecostal churches and their differences in a detailed manner, the present chapter can be treated as an excursus, introducing the reader to the boundary work of Pentecostal churches. It forms a prelude to the following chapter, which will study the boundary work of middle class Pentecostals more extensively. Therefore, the contribution of the present chapter consists in granting in-depth insights into two Pentecostal churches. The chapter is structured as follows: the first two sections portray each of the two churches in terms of their physical location, membership structure, and religious practice. The descriptions of the churches are followed by a comparison in which I directly compare the social composition and religious styles of the churches. The comparison provides some insights into the boundary work of middle class Pentecostals and therefore sets the stage for the following chapter.

\subsection{A Lower Class Church in a Middle Class Neighborhood: God Is Love}

A middle aged woman dressed in a long skirt stands in front of the pastor. The pastor asks her about her problems. In a sorrowful voice, she tells him that she has serious difficulties falling asleep and often wakes up during the night. After her description, the pastor begins a faith-healing procedure, starting with the laying of one hand on her forehand and the other on her shoulder and speaking a prayer. The woman starts to tremble and screech. Herface turns into a grimace and hervoice becomes deep. The pastor shouts: "Demon! Speak! Who are you?" No response. He thunders: "Answer, demon!" The woman cries out loudly, trembles and finally drops to the ground. "Leave this body, demon!" commands the pastor who stands above her. He calls the audience to shout with him "Fire of God! Demon burn!" An antiphony between pastor and audience starts both shouting "Demon burn!" The woman on the ground is shaking and crying. Later, she slowly calms down. Finally the pastor proclaims that she is healed. She lays on the ground some minutes longer. After standing up, the pastor asks her how she feels and she explains that she feels relieved.

This section of the study explores the case of the church God Is Love (Dios es Amor). The description above portrays a faith healing practice, which was carried out during a church service of God Is Love (GIL). This type of practice is very typical for God Is Love, as will be seen in the following subsections. 
The description of GIL is particularly fruitful since, to some degree, it represents the style of Pentecostalism from which middle class Pentecostals seek distinction. Because the form of Pentecostalism promoted by GIL clashes with the representations of the middle class, middle class churches such as Assembly of Christ, which will be described in the following section, draw boundaries in opposition to this style of Pentecostalism.

Empirically, the description is based on a large amount of empirical material consisting of ethnographic observations, qualitative interviews with members and two GIL pastors, and a quantitative survey of 75 GIL members.

The following description of God Is Love is structured thematically. First, I describe the geographic location, the history, and the architecture of the church. The next subsections discuss the organization, and the social composition of the church. After this, I explore the religious practice and atmosphere during church services. The case study ends with an explanation for the lower class bias of the church.

\subsubsection{Geographical and Religious Context of God Is Love}

The church God Is Love (GIL) is situated in Flores, a middle class district of Buenos Aires city. Flores is one of the bigger districts of the city of Buenos Aires and counts around 150,000 habitants. The church is located in the central plaza, and its entrance is front facing. As such, this public place is embedded in a fairly busy zone. It is surrounded by restaurants, stores, and bus stops, and located along Rivadavia - one of Buenos Aires' most important, noisy, and stressful avenues, highly frequented by traffic. By contrast, the adjacent plaza of Flores constitutes a small recreational area with trees, grass zones, benches, and a little playground. Here, people gather together to relax for a short time or to meet friends. They sit on the benches drinking their Maté, talk, read a newspaper or simply loiter. Some homeless people sleep on the benches. From time to time, one can listen to Pentecostal preachers standing in the middle of the plaza, preaching and seeking to evangelize their occasional audience. They come from different churches and are not necessarily related to God Is Love or any other Pentecostal church in Flores.

God Is Love is situated at the calmer extreme of the plaza opposite the noisy avenue and the huge Catholic cathedral of Flores, the basilica of San José de Flores. The church building is surrounded by a Chinese store and a restaurant on the left side, and a Methodist church and a drug rehabilitation center on the right side. ${ }^{2}$ As the zone is quite busy, there are always many pedestrians

2 Interestingly, the Methodist church next to God Is Love does not only show a very different religious style but also attracts a very different type of religious clientele which consists mainly of middle class individuals with a rather academic profile. 
crossing the doorsteps of the church. In fact, this is a strategic position for attracting potential members. But the area is not free of religious competitors. In addition to the Methodist and the Catholic Church and the frequent presence of Pentecostal preachers on the place, one can perceive numerous advertisements for witchcraft and sorcery on the bus stops and lamp posts around the plaza. Still, this imparts only a partial impression of the religious competition in Flores. Leaving the plaza but staying in the same area, there is a variety of Pentecostal competitors within the radius of only a few blocks: a five minute walk brings one to the illustrious church Cristo la solución (Christ The Solution) which broadcasts its own TV-program and has a highly sophisticated branding. The church counts around a thousand members in this branch, and several thousands in different branches around the world. Its head, the famous preacher (Apostle) Juan Crudo, is known as one of the leading figures of prosperity gospel in Argentina. Aside from Cristo la solución, there are at least two more important churches: a large branch of the Iglesia Universal del Reino de Dios (Universal Church of the Kingdom of God) is located just three minutes away on the avenue of Rivadavia and a branch of the Assembly Of God is a ten minutes' walk. Furthermore, there are numerous smaller Pentecostal and Protestant churches. Apart from the Protestant competition there are several Catholic parishes and at least one Umbanda temple. Hence, God Is Love is situated in a socio-geographic space, surrounded by religious competitors offering religious alternatives and seeking to expand their number of attendees.

\subsubsection{Origins and History of God Is Love}

The church God Is Love - Igreja Penteostal Deus é Amor - has its origins in Brazil, where it was founded by the preacher David Miranda in $1962 .{ }^{3}$ Today, God Is Love constitutes a wide network of congregations all over the world. One can even find congregations in Germany and France. However, the majority of its members are still concentrated in Latin America where its congregations are highly diffused. The center of the network is situated in Sao Paulo, Brazil. In Brazil, GIL forms part of the circle of the most influential Pentecostal churches and is the most virulent competitor of the Iglesia Universal del Reino de Dios. ${ }^{4}$

In Argentina, GIL is not as pervasive and powerful as it is in Brazil. Nevertheless, it counts around two hundred branches in the country and some 60 branches in the metropolitan area of Buenos Aires, especially in poorer neighborhoods and slums. The church arrived in 1989 in Argentina. Shortly

3 According to Pastor Mario the church was founded June 3rd, 1962 (Interview Pastor Mario).

4 Chesnut 1997: 38; Freston 1995: 128; Salas 1998: 19. 
after its arrival, it opened the branch at the plaza in Flores in 1991, which constitutes the Argentinean central of God Is Love today. Pastors of GIL describe the 9o's as a great success for God Is Love in Argentina. In the wake of the Pentecostal boom, God Is Love attracted many new members, though the growth slowed down at the start of the new century. Despite some fluctuations during the last years, the number of members in the central branch in Flores remains more or less stable and totals around four hundred active participants. ${ }^{5}$

\subsubsection{Infrastructure and Organization}

\subsubsection{Architecture and Infrastructure}

From the outside, the church building resembles a stereotypical Asian super market in Buenos Aires. The facade consists of glass windows and an entrance in its middle. Above the entrance the name of the church "Dios es Amor"

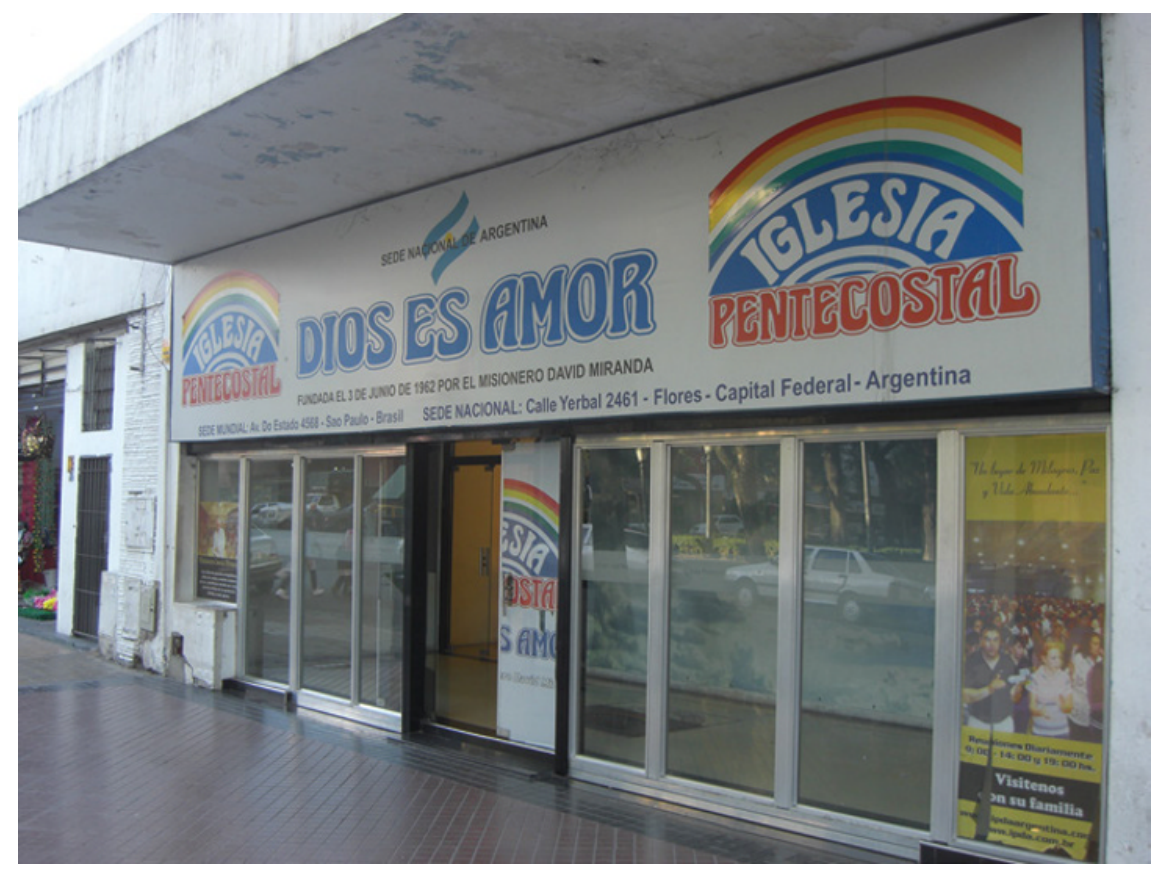

FIGURE 6 Church front of GIL

(OWN SOURCE)

5 This information is based on interviews with members and pastors of God Is Love (Interview Pastor Jorge, Interview Pastor Mario, and observation). 
("God Is Love") is written in big letters and on each side of the church name, the description "Iglesia Pentecostal" (Pentecostal church) blares in colorful letters.

The interior of the church building similarly resembles a former industrial or super market hall. After entering, one stands directly in the main hall, a very long hall with white wands from which ventilators and speakers bulk. While the entrance is situated at one extreme of the main hall, the pulpit is situated at the other. Thus, one has to cross the hall in order to arrive at the pulpit. The hall is equipped with very simple white plastic chairs, the number of which is normally adapted to the amount of visitors. Thus, during the week, only half of the hall is equipped with plastic chairs, and the space at the end of the hall close to the entrance stays empty. The main hall is very sparsely decorated. There are no video screens or projectors as in other Pentecostal churches of this size. At the left hand of the pulpit, there is a small cabinet. This cabinet serves as an information and purchase point, which is normally occupied by an elderly female church usher. ${ }^{6}$

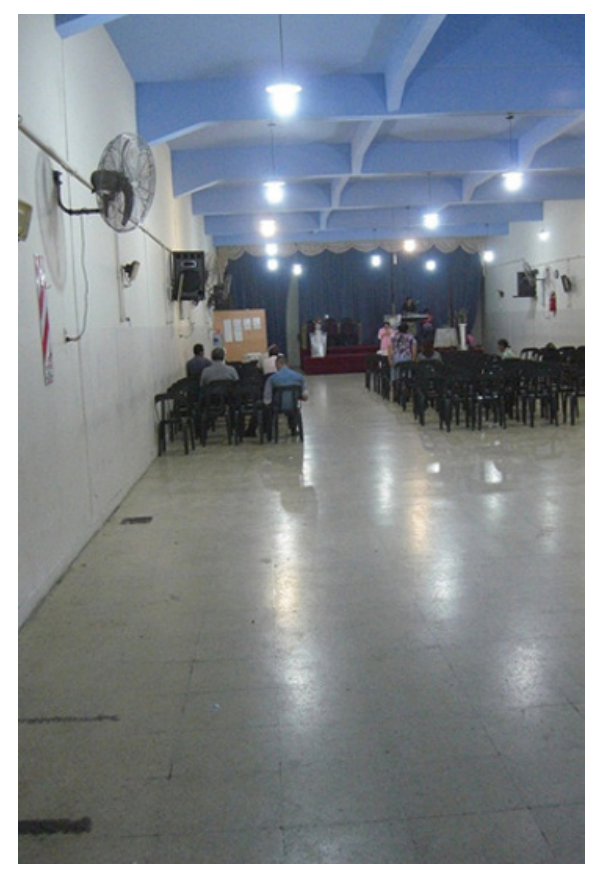

FIGURE 7

Main hall of GIL

(OWN SOURCE)

6 The church interior was renewed in 2010, so the interior is more organized today. The description here corresponds to the time period in which I conducted my empirical research in the church. 


\subsubsection{Organization of the Church}

God Is Love is not integrated into the formal circle of evangelicals in Argentina: the church is not affiliated with any of the official evangelical umbrella organizations, nor do their pastors participate in the meetings of the consejo in Buenos Aires. In these circumstances, churches are generally treated with skepticism by pastors from the formal circle. Thus, from the perspective of the formal circle, GIL has a low legitimacy in the field of Pentecostal churches. Still, pastors of GIL appear not to care much about the formal recognition of their church. Pastor Mario stated to me that GIL would not have, nor would they seek contact with any other Pentecostal church in Argentina. ${ }^{7}$ I will discuss the legitimacy of Pentecostal churches and the field of Pentecostalism in greater detail below.

The church operates seven days a week from approximately 9 am till $11 \mathrm{pm}$, and offers between two and three church services every day. ${ }^{8}$ Each day of the week is dedicated to a specific topic: Tuesday, for instance, stresses Bible teachings, Fridays are dedicated to liberation (exorcism), and on Sundays, the church performs spiritual campaigns which focus on different areas of life, such as family, health, economy or work. The most visited church services take place Fridays and Sundays and each attracts from one hundred to four hundred participants. Spiritually, these are the most intense services, and include a high number of faith healing practices and exorcisms. Less popular are the Wednesday church services, which are dedicated to Bible teachings. They attract only twenty to fifty participants.

The congregational activities of the church are largely limited to church services. For normal members or visitors, there are no courses. Also, there is an absence of church groups for members. Pastor Mario from GIL explained the lack of other organizational offers by the fact that the congregation would rather emphasize spiritual practices and miracles over the organizational structure and offers of the church. ${ }^{9}$

Several pastors are responsible for the GIL-branch in Flores. At the head of the church is the main pastor. Not only is he in charge of this branch, but also of the whole congregation in Argentina. According to the standards of God Is

7 Interview Pastor Mario.

8 Some days during the week it opens even earlier or closes later, such as on Fridays, when it remains open almost the whole night for prayers.

9 Interview Pastor Mario. 
Love, the position of main pastor rotates at least once a year: after having fulfilled his year, he will be sent to another country and substituted by a new pastor, who assumes the position of the main pastor in Argentina for one year. ${ }^{10}$

In addition to the main pastor, the central branch in Flores counts nine other pastors, who are subordinated to the main pastor. These pastors are more bound to the branch in Flores. Many of them have been in this branch for more than five years. Despite the high number of pastors, only two or three of them the ones that conduct church services - are available on a daily basis for visitors of the GIL branch in Flores. The remaining pastors are dedicated to administrative or other tasks or have a secular work life, and therefore do not conduct church services. ${ }^{11}$ Despite the high number of pastors, there are often staff shortages among pastors, resulting in problems finding a pastor to conduct the church service. ${ }^{12}$ This problem is also partly due to the fact that responsibilities of pastors are not assigned clearly. The loose organizational structure of the church perpetually creates small emergencies and leads to the assignment of pastors or ushers to different tasks, which they assume as allrounders. ${ }^{13}$ This arrangement also has a disadvantage: those who fulfill a task are often only scarcely trained in it, as shown by the example of the poor quality of music that will be discussed below.

Most pastors have a lower class background. In fact, many GIL pastors have worked or still work as construction workers, though there are also exceptions: Pastor Mario, who is dedicated mainly to the administration and radio program of the church, once started studying chemistry, but never finished his studies due to his involvement in the church. The training of pastors is carried out by other GIL-pastors, who teach occasional courses for future or recent pastors. However, the educational training of Pastors is not regarded as essential: longstanding experience, particularly the experience of the Holy Spirit, as Pastor Jorge states, is seen as more important than formal educational training. ${ }^{14}$

\footnotetext{
10 Interview Pastor Jorge; Interview Pastor Mario.

11 Pastor Mario, for instance, is in charge of the radio and administration. He does not conduct church services and is hardly present in the main hall.

12 For instance, during one of my interviews with a GIL pastor, an usher approached us several times in order to ask the pastor to conduct the afternoon service because there was no other pastor in the church. The pastor resisted and said that an usher should start the service.

13 Interview Pastor Mario.

14 Interview Pastor Jorge.
} 
The leadership of God Is Love carries a specific concept of membership. Pastors differentiate between participants and formal members, as tithing and regular participation in the church activities are far from being the only conditions for becoming a formal GIL member. Promotion to formal member requires an application from participants for this status. This application is evaluated by pastors over the course of a minimum of several months, and only if the conduct fits to the moral standards of God Is Love, will the participant be conferred the new status of formal member. Only a minority of those who participate each week in the services of God Is Love hold the formal membership status. This may be due to high costs that the status involves: formal members are required to have a sinless life style. They are supposed to reject the secular world and live detached from many of its amenities. Television and cinema, dance and non-Christian music as well as the consumption of alcohol are prohibited. Also fornication and relationships outside matrimony are strictly forbidden. Nudeness is disapproved of even within the family: married couples are expected to sleep in long clothing. Women are not allowed to wear trousers (pants), put on cosmetics, use jewelry, depilate, color their hair, or cut it short. Men are asked to wear short hair, no beard, and to dress formally for church services. Weekly assistance in Sunday church services, daily prayer, and fasting are an obligation. ${ }^{15}$ Those who are formal members or applying to become formal members have to agree to and meet these standards of conduct. To this end, they will be observed by church leaders. Only if the pastors see that the applicant obeys and appears to be spiritually prepared, will s/he be allowed to participate in the baptism and acknowledged as an official member. ${ }^{16}$

After receiving the formal member status, the status can be withdrawn by pastors if the devotee in question appears to act against the moral standards of the church. The formal status "member" is an outstanding status among regular participants. Only approximately 80 participants are formal members of GIL. Numerically, regular participants - or non-formal members - form a much larger portion of GIL. Despite the fact that they do not hold the formal status of members, they tend to call themselves members of "God is Love". Therefore, I will use a broad definition of members, transcending the formal membership concept of GIL, and define

\footnotetext{
15 Interview Carolina Part 3.

16 Interview Matias.
} 


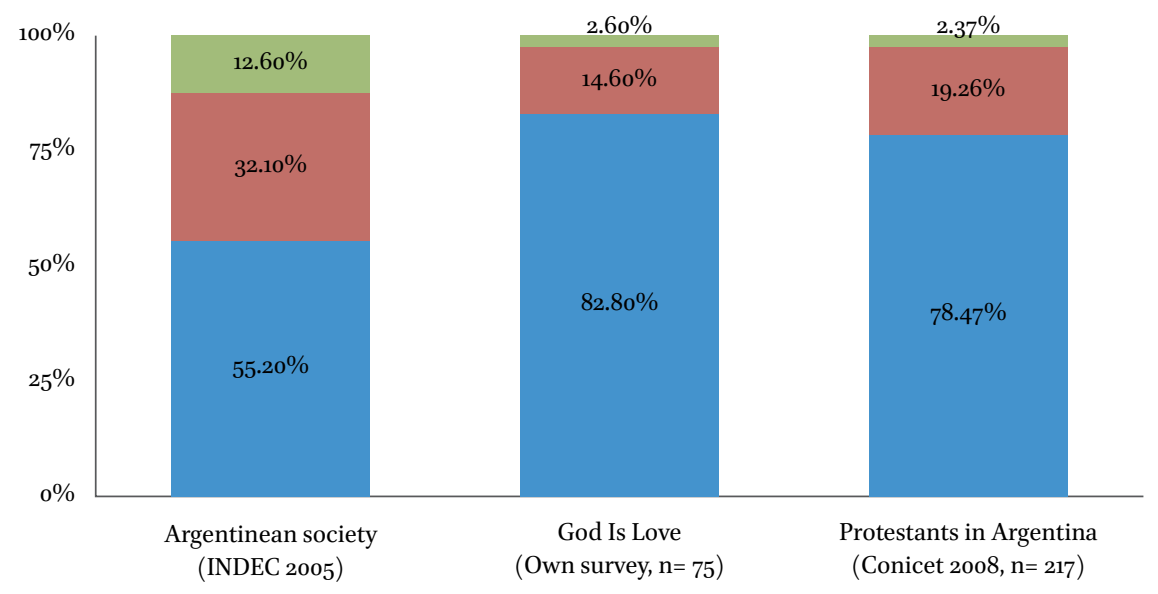

Incompleted Secondary School $\quad$ Completed Secondary School $\quad$ Completed Higher Education

FIGURE 8 Level of education: Argentinean society, members of GIL, and Protestants (OWN COMPOSITION BASED ON CONICET 2008, INDEC 2005, AND OWN SOURCE)

members as individuals that participate on a regular basis in the church services of GIL and define themselves as members of GIL. Applying this definition, the number of members in this central branch can be estimated at approximately four hundred.

\subsubsection{Social Class Background of Members}

The number of members that frequent the G I L branch in Flores on a regular basis can be estimated to be approximately four hundred, around two thirds of which are female. Astonishing is also the low presence of adolescents in this figure. The vast majority of members fall under the ages of 40 and 70 years. However, more important for the topic of this study is the social class background of members. As mentioned above, a survey was conducted in order to determine the "objective" social class position of members. For this purpose, data concerning the formal education, household income, number of household members, and job occupation of members was collected.

Formal education is a central determinant of class position. Figure 8 shows the formal education of GIL members in relation to that of Argentinean society (according to the INDEC 2005) and Protestants in Argentina (according to Conicet 2008). 
The bar in the middle of the figure demonstrates the educational degrees of the 75 interviewed GIL members. One can compare the educational composition of GIL to that of the Argentinean society, shown in the first bar: while $55.2 \%$ of Argentinean society does not hold a secondary school degree, the proportion of those who do not hold a secondary school degree is $82.8 \%$ among GIL members, showing lower levels of formal education than the average Argentinean population. Moreover, comparing the educational composition of GIL to that of Protestants in Argentina, shown in the right bar, it is evident that the educational composition of GIL is fairly similar to that of Protestants.

The second crucial variable to determine the social position of an actor is his/her economic capital. This study uses household income per capita in order to determine the economic capital of an actor. Figure 9 compares the household income per capita of GIL members and the Argentinean society along four income groups. ${ }^{17}$

Of the interviewed GIL members, $60 \%$ are in the group that receives the lowest household income per capita in Argentina. They live in poverty or close to poverty. The next group embraces $21.33 \%$ of GIL interviews. Combining the proportion given in the two lowest income groups, one can estimate that at least $81.33 \%$ of GIL members are economically situated in the

17 The data for the Argentinean society is taken from the INDEC (2015) and represents the distribution of household income per capita in the Argentinean society in the second quarter of 2009. This corresponds with the time in which the surveys in GIL and Assembly of Christ (AC) were conducted. The data that is normally given in deciles and was summarized in four income groups illustrated by the blue bars: the first group embraces the $30 \%$ of the Argentinean society with the lowest household incomes per capita. Households in this group receive a household income per capita below $55^{2}$ pesos (equalizing approx. 155 Us Dollars based on an exchange rate of 3.55 Arg. Pesos per us Dollars). These households can be defined as poor or close to poverty. After this group follow two groups which each represent the next $20 \%$ of the Argentinean society: the first income group can be defined as an economically more or less stable lower class (552-820 Arg. Pesos; equalizing approx. 155-231 us Dollars). The next income group is located on the boundary between middle and lower class and can be defined in economic terms as the lower middle class (820-1300 Arg. Pesos; equalizing approx. $231-366$ us Dollars). Finally, the last $30 \%$ receives the highest household incomes per capita with more than 13001 Argentinean pesos each (equalizing approx. 366 us Dollars). This income group embraces the established middle and the upper class. 


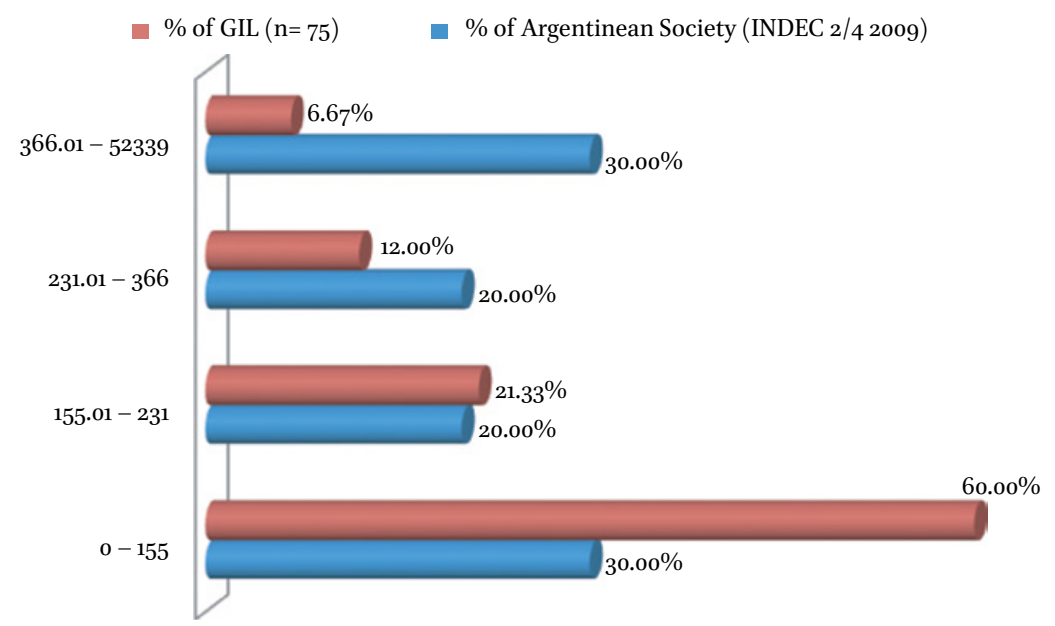

FIGURE 9 Household income per capita in US-Dollars: GIL and Argentinean society (OWN COMPOSITION BASED ON INDEC 2009 AND OWN SOURCE)

lower class. ${ }^{18}$ A comparison between the bars illustrates the disproportions between the household income of GIL members and the Argentinean society: members of GIL are highly overrepresented in lower income sectors and underrepresented in higher income sectors. Put simply, members of GIL have lower economic means than the average Argentinean population.

A variable that contributes additional information about the social status of members is job occupation. Many members stated that they are unemployed and make a living from chamba, casual jobs. Those who have work are mainly occupied in the unstable, informal economy. Typical employments of female church members are domestic assistants, domestic nurses, and self-employed sellers of home-prepared food in the streets of Buenos Aires. Male members are often caretakers and doorkeepers of middle class buildings, construction workers, painters, and assembly line workers.

Taking all these variables together it becomes clear that God Is Love mainly attracts individuals from the lower social positions of the Argentinean society: GIL members tend to be poorer, less educated, and work in lower-status jobs than the average Argentinean. Despite its location in a middle class suburb,

$1812 \%$ of GIL members are situated on the boundary between lower and middle class and just $6.67 \%$ are economically positioned within the established middle class. 
the social composition of the church is dominated by the lowest ranks of the Argentinean society, raising the question of why the church attracts mainly the lower class and appears to have no appeal to the middle class. Besides the already discussed structural and organizational features, the religious practices may play an important role for explaining the lower class bias of the church.

\subsubsection{Religious Practice}

The devil has stolen your wealth. The devil has stolen your peace. The devil has stolen your family. He has torn down your hopes. This mission continues to defeat evils. Stop your mourning. You will defeat the spirit of death, the spirit of cancer, the spirit of sickness. God will defeat them. God gives you authority.

GIL Church service 22nd May 2009 00:20:41-4-00:21:20-9

Church services are the most important and basically the only regular congregational practice of GIL. The church offers at least two church services each day, seven days a week. The most important church services take place Sundays: the two services attract up to 800 visitors, many among them first or second time visitors and members of other GIL branches visiting the central branch. The second most important church services, in terms of numerical attendance, take place Friday and emphasize spiritual warfare. Due to their importance, I will stress Sunday and Friday church services in the following description.

Church services last between three and six hours and vary in their structure and opacity. Although there appears be no fixed or repeating structure, one can nevertheless try to draw a rough picture of the general structure. Church services start generally with prayers and music. The subsequent principal part of the church service consists of the pastor speaking, performing prayers as well as different types of spiritual practices, offerings, singing, and testimonies. The church service ends with prayers, laying on hands and the blessing with oil.

Many of the practices take place several times and are mixed with each other. During the main part, the pastor might suddenly switch between different practices: he may, for instance, switch from preaching to singing, come back to preaching, announce a prayer without carrying it out, sing again, and start a prayer which ends up in an exorcism. Hence, the structure appears to mainly depend on the intuition and experience of the pastor. 


\subsubsection{Musical Praise}

Musical praise generally takes place at the beginning and several times over the course of the church services. Background music also frequently accompanies the pastor while he is carrying out prayers, declarations, and other spiritual practices.

The church has no orchestra or band; the only musical instrument is a keyboard situated on the pulpit in combination with a microphone. As such, the keyboard player regularly assumes the role of the main singer. A small church chorus also occasionally performs short concerts during Sunday church services. Nonetheless, the singing accompanied by the keyboard normally constitutes the bulk of the musical program. The keyboard is played by ushers or pastors, who neither are very well-trained piano players nor are they singers. Despite playing rather simple rhythms, they tend to play unevenly and may miss a note from time to time or sing off-key.

Typical types of music are ballads and cheerful, folkloric Latin-American rhythms that frequently resemble cumbia. Often, the pastor will suddenly animate the audience after a prayer or during his sermon to sing some short and repetitive refrains.

A song that is very typical in GIL is the emotional ballad "Gracias". The refrain says "Gracias, Gracias Señor, Gracias mi Señor, Jesús, Gracias, Gracias Señor, Gracias mi Señor, Jesús." Participants raise their arms while singing. During more empowering songs, participants clap their hands and sing loudly.

There is a notable difference in the emphasis on music, especially in comparison to other medium-sized churches that generally have at least a small band with a drummer and guitar player. GIL places less emphasis on musical praise than other Pentecostal churches, justified by pastors by the lack of organization and trained staff, instead focusing on other practices such as spiritual healing and exorcisms. ${ }^{19}$

\subsubsection{The Sermon}

Pastor Mario estimates that the maximal length of sermons is 15 minutes. ${ }^{20}$ Taking the full length of the church service into account, often lasting between

\footnotetext{
19 Interview Pastor Jorge.

20 Interview Pastor Mario.
} 
four and five hours, the length of sermons appears as extremely short, comparatively speaking. ${ }^{21}$

Sermons generally begin with a short citation from the Bible. After this, the preacher starts his sermons, though he does not necessarily focus on the Bible quote. Frequently, the sermon consists of a narrative of a life experience that exemplifies the work of God in everyday life. The narratives include a lesson about the power of God and may illustrate how devotees can receive God's blessing - a blessing that potentially means an end to the empirical afflictions and an improvement of the daily life. The subject of sermons is often related to the concepts of prosperity gospel and spiritual warfare.

The religious discourse alludes heavily to the action of evil and divine forces in the empirical world. The pastors' language is dominated by a vocabulary of struggle with these evil forces and their eventual defeat. Words like "fight", "combat", "war", "victory", "defeat", "justice", "enemies", "power", "Satan", and "demons" are highly recurrent in the preaching. The enemy is defined as Satan and his dark forces including demons, bad spirits - particularly spirits of macumba and umbanda - and those who follow them. Devotees are located in the center of this war between divine and evil, where their suffering and daily problems are attributed to malicious spirits. Individuals affected by problems like alcoholism, disease, or unemployment are described as victims of these forces. Thus, empirical afflictions are regarded as the product of spiritual afflictions.

According to the discourse of GIL, only God - and more particularly the power of the Holy Spirit - can break the spiritual affliction and open a new path. Furthermore, God might not only eradicate the root of evil in the life of the individual but grant him/her prosperity and realize his/her desires. Sermons announce the immediate beginning of a new and better life, a life free of afflictions, a life of well-being. To reach this new life, the chains that bind one's fate to the will of Satan must be cut. ${ }^{22}$ The most important instrument for cutting the evil chains is thought to be the expulsion of the dark forces that keep the devotee imprisoned in his/her suffering by means of spiritual practices. These practices refer to the power of the Holy Spirit and its gifts, as will be shown below.

The atmosphere during the sermons is rather expressive. The pastor may shout from time to time and participants exclaim frequently in a loud voice

\footnotetext{
21 Yet, there are often several contributions during one church service that may be also described as sermons. Due to the frequent combination of preaching and spiritual practices, it is difficult to classify these parts of the church service as sermons. 

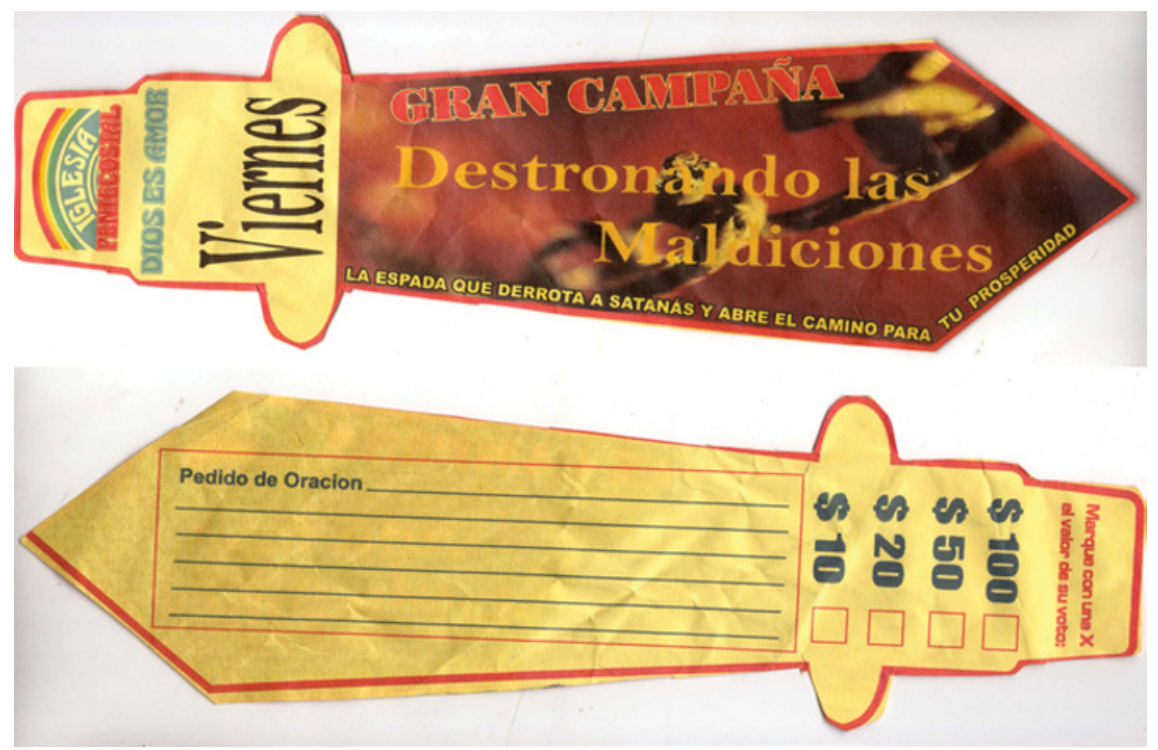

FIGURE 10 GIL offerings "Elvoto"

(OWN SOURCE)

"Gloria a Dios." These exclamations occur particularly when the pastor narrates a divine miracle or explains the central lesson proclaiming the divine victory over evil forces. Moreover, the pastor integrates the participants actively into the sermon by asking repeatedly, "Cuantos dicen Gloria Dios?" to which the audience responds, “Gloria a Dios!”.

\subsubsection{Offering and Tithing}

Offerings and tithing are important parts of the service. The pastor may ask up to three times during a church service for different types of economic contribution. Of particular importance are the so-called votos. The voto is a donation in a specific paper envelope and represents a contract-like request to God. One example of a voto is exhibited in figure 10.

The voto in figure 10 was used for one of the spiritual liberation campaigns on a Friday. The voto has the form of a sword and shows the image of a chain getting disrupted. Apart from the name of the church and the indication of the day (Friday), the phrase "Destronando las maldiciones" ("Dethroning the curses/afflictions") is written on the voto and below, in smaller letters, "La espada que derrota a Satanas y abre el camino para tu prosperidad" ("The sword that destroys Satan and opens the way for your 
prosperity."). On the back, there is a space where the devotee can indicate the amount of money put in the voto and another part where s/he is supposed to write down his/her request to God. The image of the voto is quite clear: this sword and its content (the offering) are supposed to fight and destroy the spiritual afflictions that cause the empirical afflictions in daily life. The chains on the voto illustrate that the 'ataduras' (knots that spiritually bind the devotee to his/her afflictions) are believed to be disrupted and that the devotee will be relieved with this voto from the spiritual barriers in order to prosper.

Every week, the color, shape, and lettering of the envelope changes, and they are usually they titled with phrases that refer to the destruction of demonic forces. The envelope has a free space wherein the adherent should write down his/her requests to God. ${ }^{23}$ Devotees will write their request in the free space, indicate the amount of money that they sacrifice for their request to God, and put the amount in it. After retrieving the voto, pastors bless the envelope again and perform a strong prayer.

Votos are believed to have a spiritual dimension. They form a type of spiritual contract with the supernatural. The devotee expects a specific spiritual service for the payment. This spiritual service will usually be a divine miracle requested on the overleaf of the voto. The procedure and discourse of GIL suggest that the higher the donated amount, the higher the effectiveness of the voto and the probability of fulfillment of one's request.

\subsubsection{Spiritual Practices}

The majority of the church service is dedicated to a mix of preaching and spiritual practices. Spiritual practices are practices that aim for an improvement of the empirical reality through an intervention of the supernatural. GIL shows a high emphasis on spiritual practices, particularly on those involving miracles and faith healing. Because of this focus, the church is often described as a "spiritual emergency room".

23 Votos get distributed one week in advance and are collected with the offering in the following week. Before they are distributed among participants, they are blessed with oil and a prayer. For the distribution of votos, pastors call out amounts of money starting with high amounts - such as one hundred Argentinean pesos - and decreasing the requested amount during the distribution. Devotees who want to donate the requested amount are asked to come to the pulpit and get the voto. The lower the requested amount becomes, the more devotees approach the pulpit to get the voto. 
Spiritual practices refer to a wide variety of practices. The most common of them in GIL are prayers, declarations, prophecies, blessings, laying on hands, faith healing, and exorcisms. I will briefly discuss each of these practices in the following paragraphs.

Prayers are an important spiritual practice in GIL. They usually request specific favors from God. These requests are related to the economy, health, harmony of family or general wellbeing of devotees. Prayers are often carried out in an authoritative and demanding form. Pastors may shout loudly while participants raise their arms, start to tremble and speak in tongues. ${ }^{24}$

Prayers are frequently combined with prophecy, a very prevalent practice among GIL pastors. Prophecies generally concern the future but also past or present states of individuals in the audience. Thus, often pastors name the afflictions of individual participants present in the church. In this case the pastor may announce, for instance, "There are three persons with heart problems present in the church." However, he will not directly indicate the afflicted individuals; instead, they must declare themselves. After naming an affliction and a number of individuals affected by it, the pastor asks the affected individuals to raise their arms and to approach the pulpit, where he blesses them with oil, lays hands on their foreheads, and performs a prayer or even exorcism with them. After this, he announces the next affliction and the number of persons suffering from it calling, for instance, three unemployed participants to the pulpit.

A major part of the church service is dedicated to techniques of spiritual healing. These techniques consist of laying on hands, blessing the person with oil, faith healing, or performing exorcisms. The difference between these practices is often not clear, and often they melt into one another. The pastor may start, for instance, with laying on hands on the forehead of a participant and perform a prayer. The participant starts to tremble and the pastor states that the individual is possessed by a demon. In this case, the practice will turn into an exorcism, in which the pastor will shout loudly exclamations such as "fuera demonio!" ("demon leave!") and "quema demonio en el nombre de Dios!" ("demon burn in the name of God!"). At the same time the participant in question may manifest him-/herself in different ways, such as shouting, trembling, and/or

24 The style and atmosphere of declarations is similar. However, declarations form, rather a mix of a prayer, a promise, and a prophecy. Declarations announce the existence of a (new) state. This may be, for instance, a change in the life of the individual. In order to perform a declaration, the pastor asks the participants to stand up, raise their arms, and repeat what he will say. These declarations may last several minutes announcing the power of God and the change to one's life. 
dropping to the ground. The exorcism generally ends with the participant lying quietly on the ground. After resting on the ground for several minutes, $\mathrm{s} /$ he will stand up again and the pastor may ask him/her to testify how s/he feels and if $\mathrm{s} /$ he thinks that the suffering has disappeared.

Frequently, pastors also perform strong prayers involving spiritual warfare and merging with exorcisms. During these prayers participants stand in their places. They are asked to raise their arms or put their hands on their heads. While the pastor performs the prayer in the front, shouting "fuera, fuera, fuera!" ("leave, leave, leave!"), participants start to tremble, ushers move through the rows of seats in order to lay on hands, and some participants drop to the ground.

Another very important practice is the blessing with oil. The pastor puts the oil on the forehead of the devotee and intones a short prayer. Then, the next devotee follows. There may be various blessings with oils for different areas of life during one worship. Similar to other spiritual practices, they can easily convert into practices of faith healing or exorcisms when a participant manifests signs of a spiritual possession.

Spiritual practices do not only integrate the body of participants, but frequently also objects that participants bring to the church service: pictures of relatives, keys, wallets, pieces of cloth from relatives, contracts or certificates of debt, and bottles of water are often combined with spiritual practices. Bottles of water and pieces of cloth from ill relatives are placed close to the pulpit, where they are supposed to get blessed. Wearing the blessed cloth and drinking the blessed water is believed to cure the ill and protect the healthy. By contrast, items such as pictures of relatives, keys, wallets, or contracts are raised during prayers. By raising these items, participants present a request related to the item. Raising a wallet implicates, for instance, a request for the protection and/or prosperity of the economy of the household. Pastors may also ask participants to raise their keys and pray with the participants for the spiritual protection of house and family. This technique is believed to protect the home and inhibit the entrance of evil spirits.

Another, very prevalent type of practice in GIL is that of repetition. Practices of repetition are specific practices that the pastor or preacher asks the audience to perform. These practices may consist of a physical movement, the repetition of a phrase or word, or a combination of both. Pastors ask the audience, for instance, to recurrently raise their arms, to wave their hands, to trample with their feet on the ground, to hug themselves, to put their hands on their heads, or to say a phrase to their neighbor. These practices are performed over and over again during the whole church service. 


\subsubsection{Explaining the Class Bias: GIL as a Popular Style of Pentecostalism}

Although GIL is embedded in a middle class district of Buenos Aires, it attracts predominantly the lowest ranks of the Argentinean society. Its class bias raises the question of why it attracts predominantly the lower class and not the middle class. The central factor that contributes to an explanation of its social composition appears to be GIL's religious style. Features of the religious style of a church are its infrastructure, organization, and religious practices.

The church building of GIL is a rather simply decorated building, resembling an old industrial hall. Regarding its relationship to the formal circle of evangelical churches in Argentina, the church is not affiliated with any of the evangelical umbrella organizations nor does it seek the interchange with other Pentecostal churches. Moreover, the organization of GIL is not very developed and the assignment of tasks is described as rather chaotic. GIL does not offer courses, groups, or other activities to its members and focuses, instead, on providing a high number of church services. Thus, church services basically form the only congregational practice of GIL. The religious practices during church services stress the afflictions of participants, tracing them back to malicious spirits. The spiritual treatment of these afflictions assumes a major importance in GIL, which enjoys the reputation of being a spiritual emergency room. The spiritual treatment is carried out by different practices such as praying, offering, blessing, faith healing and exorcisms. In order to perform these practices, pastors frequently raise their voice and shout, while participants might cry out, speak loudly in tongues, tremble, and fall to the ground. Hence, church services assume a very emotional and expressive atmosphere, where throughout the church service, participants experience emotional ups and downs. Thus, for an outsider observing, the church service may appear like an emotional roller coaster ride.

Characteristics that are usually portrayed as typical for Pentecostalism are very pronounced in GIL. Most of them are related to the gifts of the Holy Spirit such as speaking in tongues, prophecy, healing, driving out demons, etc. Also, the emotionality and expressivity during church services and the belief in the action of supernatural forces in daily life are strongly emphasized in the practices and discourses of GIL. Apart from spiritual warfare, one can also observe elements of prosperity gospel. Although pastors criticize other Pentecostal churches - such as Cristo La Solución - for their focus on prosperity gospel, G IL does not abstain from employing these concepts. ${ }^{25}$

Remarkably, some of the practices of GIL strongly resemble those of popular Catholicism. This cultural proximity becomes particularly evident when

25 Examples for this are spiritual practices that are believed to improve the economic situation of devotees. 
examining the prayers with objects, such as keys, photos, and the blessing of water. Similarly, the idea of sacrifice - or payment - for divine "services" in GIL, which is very pronounced in the offering with votos, also strongly resembles requests to the Santos in popular Catholicism where devotees seek favorable spiritual interventions for a "payment".

The practices in GIL appear not only to be shaped by popular Catholicism but also by popular culture and religion in general. As described above, the style of GIL embraces many characteristics that are generally attributed to popular religion. These overlaps are not limited to religious pragmatism, which focuses on resolving empirical problems by spiritual interventions, but also encompass the festive and expressive atmosphere of church services, and the holistic worldview. Further, this includes the style of the music, which is rooted in popular culture.

The accentuation of popular religion and culture in the style of GIL may explain its appeal to the lower class. Still, this does not necessarily explain why the Argentinean middle class abstains from GIL. Apart from the match between the church style and popular religion, there seems to be another reason for the social composition of GIL: its "inappropriateness." In the interviews, I showed videos from GIL to middle class Pentecostals. They reacted sometimes with mockery, sometimes with indignation, but always with a type of rejection. The reactions indicate that there is a mismatch between what is regarded as appropriate by the middle class and the religious style of GIL. This could explain GIL's low appeal to the middle class, who prefers churches with styles that they experience as more appropriate. One of these churches is Assembly of Christ, which will be portrayed in the next section.

\subsection{A Case Study of a Middle Class Pentecostal Church:The Assembly of Christ in Villa Devoto}

This section explores the case of the middle class church Assembly of Christ (Asamblea Cristiana). The case of Assembly of Christ (AC) illustrates the boundary work of middle class Pentecostals. By developing a distinguished style of Pentecostalism, AC sets itself apart from other Pentecostal churches. In an analogy to the previous section, the empirical data is based on ethnographic observations, qualitative interviews with members and two AC pastors, and a quantitative survey of $87 \mathrm{AC}$ members. The section is structured as follows: the first subsections describe the physical location, history, organization, and the social composition of AC. This is followed by a subsection portraying the religious practice of $\mathrm{AC}$, and the last subsection summarizes the attributes that $\mathrm{AC}$ employs in its boundary work. 


\subsubsection{Geographical and Religious Context of Assembly of Christ}

The Assembly of Christ (Asamblea Cristiana, AC) is located in the southwest of the Argentinean capital, in the middle class neighborhood of Villa Devoto. Devoto is a calmer and less busy metropolitan district than Flores. Instead of tall, multi-storied buildings, the panorama is dominated by small buildings and family houses. Situated a bit remotely from the main plaza and the shopping area, in a rather quiet residential part of Devoto, the church is not strategically located to attract many curious passersby. The church lies on a broad street and is surrounded by two- to three-story apartment buildings and family houses. The median strip of the street is planted with grass and small trees, contributing to the calm atmosphere of this area of the capital. Behind the church passes a city highway that surrounds the capital. A bridge connects this part of the capital with some lower class districts of Buenos Aires province.

There are several religious competitors in the surroundings of the Assembly of Christ. Aside from the ubiquitous Catholic competition, there are various smaller and medium-sized evangelical churches, for instance the Iglesia Cristiana Biblica, Ministerio Ebenezer, Christo El Rey, Iglesia La Puerta Abierta, and a branch of the Assembly of God. One of the pastors of AC estimates that there are around 1o Protestant churches in a radius of 10-15 blocks around the AC. ${ }^{26}$ Apart from the Protestant and Catholic competition, there are other religious competitors like a new age faith center located at one end of the street leading to AC. Furthermore, walking down the roads in Villa Devoto, one can see from time to time an advertisement for spiritual services on lamp posts.

Despite the presence of these competitors, the religious competition is, in fact, not as intrusive as in the case of the church God Is Love (GIL), which is closely surrounded by religious rivals.

\subsubsection{Origins and History of Assembly of Christ}

The Assembly of Christ was founded in 1907 by Italian immigrants in Chicago, USA. Missionaries from this congregation arrived in 1909 in Buenos Aires, Argentina. The first congregational activities in Villa Devoto began in 1916. In the subsequent time, members started to organize regular meetings with a growing group of participants in different locations in Villa Devoto. The continuous growth of the congregation culminated in the construction

26 Kravetes 2008; Saracco 1989: 43-54; Stokes 1968: 17-19; Interview Pastor Victor Part 2. 
of the church building from 1923 onwards. Today, this temple functions as the headquarters of Assembly of Christ in Argentina, including in its jurisdiction hundreds of temples and approximately ten thousand members in Argentina. ${ }^{27}$

Due to its early arrival in Argentina in 1909, the Assembly of Christ movement stands at the very beginning of Pentecostalism and marks the commencement of the first wave of Pentecostalism in Argentina. In fact, for its centenary in 2009, the church received a distinction from the Argentinean Secretary of Cults, a governmental institution, recognizing it as the first Pentecostal church in Argentina. Another central characteristic of AC is its Italian background: until the 196os the congregation was dominated almost exclusively by Italian immigrants. ${ }^{28}$ However, in the last decades, the congregation has undergone significant changes in its leadership and the form of its administration. According to one of the pastors, Pastor Victor, the old leadership was marked by a lack of education. Many of the leaders were even illiterate. During this time, the church was shaped by an old-fashioned style of Pentecostalism that placed an emphasis on religious experience, the Holy Spirit, and religious traditions. The new leadership substituted this old style with a new style, which has established a more liberal order and focuses on education and Bible teaching. Not everyone welcomed the changes. Many of the old-established Italian families who had marked the founding of the church left the congregation. ${ }^{29}$ During its evolution, the membership of the church became increasingly middle and upper-middle class. Some of the existing members experienced upward social mobility, while many of those who affiliated as new members came from a middle class background. ${ }^{30}$

In 2010/2011 the pastors estimated that the church had approximately 500 active members. ${ }^{31}$ According to my own estimations the number of active members who participate in the church services on a regular basis is a bit lower, approximately 300 to 400 . The majority of members are from the middle class. Therefore, the social composition of the Assembly of Christ in Devoto is exceptional for Pentecostalism in Argentina, as will be shown later.

\footnotetext{
27 Interview Pastor Nicolás.

28 Kravetes 2008: 99-100; Saracco 1989: 52-54.

29 See Interview Pastor Victor Part 1; Interview Pastor Nicolás.

30 See Interview Pastor Nicolás.

31 See Interview Pastor Victor Part 1; Interview Pastor Nicolás.
} 


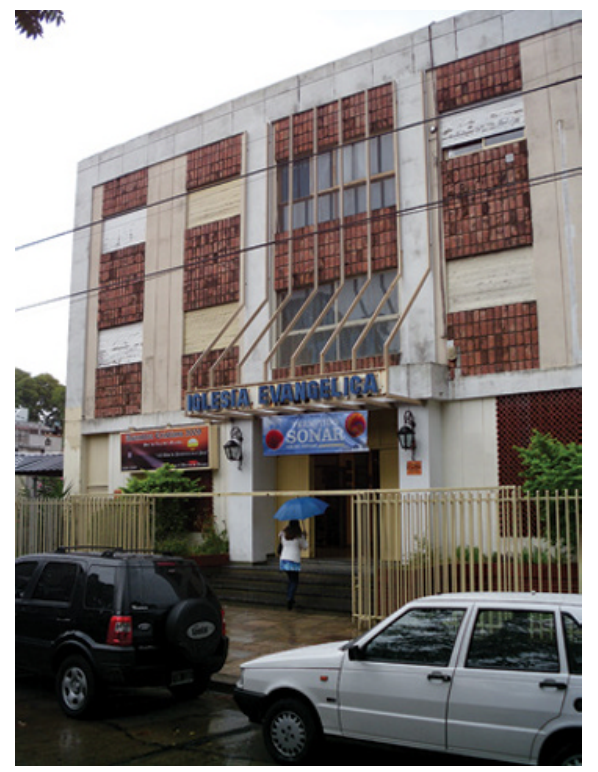

FIGURE 11 AC church building

(OWN SOURCE)

\subsubsection{Infrastructure and Organization}

7.2.3.1 Architecture and Infrastructure

Knowing that the Assembly of Christ in Devoto is one of the Pentecostal churches with the highest socioeconomic compositions in Buenos Aires, one would expect perhaps a modern building with luxurious, glamorous inner architecture, comfortable furnishings, and highly advanced electronic equipment. This is, however, not the case. The church, though not particularly shabby, poorly equipped, or minimalist, is definitely less glamorous and less well equipped than some of the lower middle class churches in Buenos Aires, like for instance the Neo-Pentecostal church Cristo La Solución, which has highly modern electronic equipment and very modern inner architecture. The furnishings and inner architecture of AC seems to reflect its religious discourse, which argues against the focus on outer appearances, particularly material wealth, and fights prosperity gospel, as will be discussed later. Nevertheless, AC is still better equipped than God Is Love and most other Pentecostal churches.

The temple of Assembly of Christ is a three-story, building in a square, bulky shape. The facade of the temple is built with bricks and cement, and a sign above the main entrance indicates in big letters "Iglesia Evangélica".

In contrast to God Is Love, the building was originally constructed as a church. Entering the building, one stands in the entrance hall. On the left hand side is a shop with a wide range of merchandise, such as Christian books, calendars, 


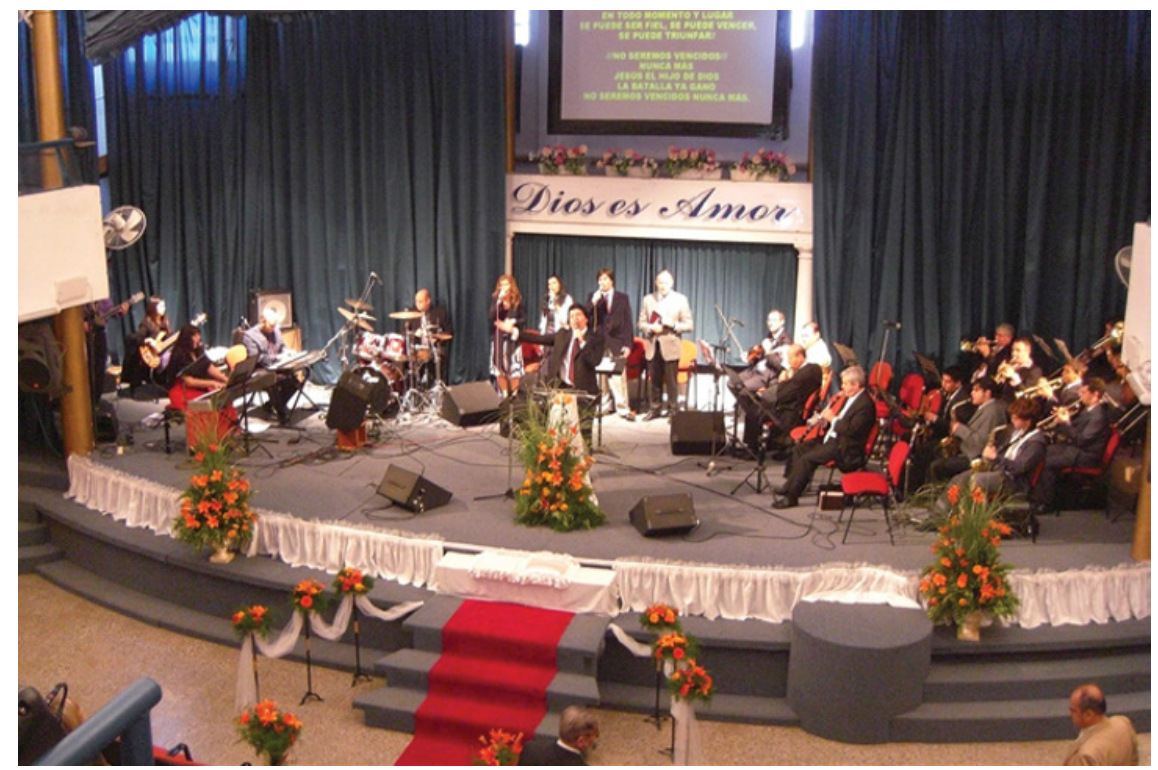

FIGURE 12 AC church orchestra playing during a marriage (OWN SOURCE)

music and DVDs as well as different evangelical magazines. On the wall, there are three golden plaques commemorating the 1ooth anniversary of AC in Argentina. One of them is the official recognition from the Argentinean Secretary of Cults, defining AC as the first Pentecostal church in Argentina. On the right hand side, one sees different notice boards with official church announcements, advertisements for special events as well as announcements of church members.

Crossing the entrance hall, one arrives at the main hall. The main hall has the appearance of a theatre. It has the shape of an oval and consists of two levels. The lower level accommodates four rows of cushioned, comfortable chairs capable of accommodating around $25^{\circ}$ people. Instead of air-conditioning, some old looking ventilators protrude from the walls into AC's main hall. The upper part offers seating space for another 200 people on less comfortable plastic chairs, installed as seating rows that resemble those of a soccer stadium. The pulpit is located on a large stage, offering a broad space for the church orchestra. A large curtain hangs across the back of the stage. In its center is written the phrase "Dios es Amor" ("God is love") in huge cursive, above which is positioned a big white screen for video projections. ${ }^{32}$ In the upper part of the church, there are

32 "Dios es amor" ("God is love") is a religious expression which has in this case no relationship to the church God Is Love. 
administrative offices and meeting rooms for church groups (and two locations for the audio-visual team). The cellar of the church accommodates a large cafeteria with sporadic hours of operation. From the back, the church is connected to a modern building where the church runs its primary school and kindergarten.

\subsubsection{Organization of the Church}

The church is enrolled in the two most important umbrella organizations of evangelical Protestantism in Argentina, FECEP (Federación Confraternidad Evangélica Pentecostal) and ACiera (Alianza Cristiana de Iglesias Evangélicas de la República Argentina). The main pastor of AC holds the chair of the FECEP, and was previously second chair of the ACIERA. In addition to this position, he is the head of the theological institute Seminario Biblico de Fe which has according to its webpage - around 80 branches in and outside of Argentina. ${ }^{33}$ Moreover, he is enrolled in the Buenos Aires city council of pastors (Consejo de Pastores de la Ciudad de Buenos Aires), where he maintains close contact with other important figures of charismatic Protestantism in Buenos Aires. Consequently, AC is deeply integrated into the formal circle of evangelical Protestantism in Argentina. Its strong integration into the formal circle of evangelical Protestantism, the position of the main pastor and the fact that AC is the oldest Pentecostal in Argentina confers a high status upon this church.

The church has three pastors: at the top of the inner church hierarchy is the main pastor. When the main pastor is not present because of his various commitments in different religious organizations, the second line of pastors in charge which consists of a businessman and an accountant who dedicate their leisure time to the church.

The church is organizationally split into different ministries, each constituting a group of members headed by a leader. One of AC's pastors estimates around 125 operational ministries in the church, since every ministry includes other ministries. Some of them are, of course, less active than others.

The most important of these groups are the discipulados (disciple groups). Discipulados are groups of four to ten members, split according to sex, age, and family status. There are groups for men, women, the youth, families and young couples. In these groups members meet on a regular basis to read and discuss passages of the Bible, pray, and talk about particular difficulties in their lives. In addition, they may organize worships and special church events from time to time.

Another organizational feature of the church is its primary school. The church runs a state recognized school, which provides primary level education 
to children from Protestant families. Since the school has a good reputation and charges comparatively low school fees, even Protestants from other churches send their children to this school. In 2010 a new, three storied school building was inaugurated at the back-side of the church.

Christian education for children and teenagers is conducted in the dominical school, which consists of different classes and often contributes with performances to the Sunday church services. Additionally, the church works in close relationship with the Seminario Biblico de Fe. Many of its members study in this Biblical institute and some of its courses take place in the church building.

AC is also engaged in different social projects. For instance, the church sends cloth, school equipment and food into poorer provinces in the north of Argentina. ${ }^{34}$ Laura, a member of AC, is very enthusiastic about the social projects of AC, though the social help projects of AC, she explains, are closely bound to the socio-economic positions of its members. ${ }^{35}$ Social projects appear to enable AC to exhibit its exceptional social position and to receive in return for its social engagement social recognition.

Concerning its presence on the internet, AC has three internet-pages: the official one from the church (http://www.asambleacristiana.com.ar/), a Facebook page from the church (https://www.facebook.com/AsambleaCristiana Devoto) and another Facebook page maintained by the youth group (https:// es-la.facebook.com/jovenes.ac). ${ }^{36}$ The official page includes information about the church's history, the school of the church, and the Bible institute Seminario Biblico de Fe; it does not contain information concerning church events or news. The Facebook page for the youth group is maintained on a more regular basis and includes information about past and coming events from the church youth.

Summarizing, the AC branch in Devoto has developed an extensive organizational body given its quantity of members. The organizational structure is manifested in a wide range of activities and services. In addition to the ordinary church services, the church supplies a range of different religious and secular services to members and non-members. Education plays an important role in AC's organization and culture. ${ }^{37}$ The value that is attributed to education exhibits itself in AC's strong connection to the theological

\footnotetext{
34 See Interview Pastor Nicolás; Interview Pastor Victor Part 1.

35 Interview Laura.

36 Internet links last accessed at 9th April 2015.

37 See also Interview Pastor Nicolás.
} 
seminary, its school, the wide range of courses that are offered in the church, the dominical school, and also in the rhetoric of pastors and its members.

\subsubsection{Social Class Background of Members}

The majority of the approximately 400 members are situated socially in the middle class and upper middle class. In a few cases, members are even from the upper class.

A glance at the level of education of Assembly of Christ members, as compared to the average Protestants in the Conicet survey, ${ }^{38}$ illustrates the exceptional social position of AC-members among Protestants.

Figure 13 exhibits the education level of the 87 interviewed AC-members, as compared to those of Protestants from the Conicet survey conducted in 2008 and to the general educational distribution among the Argentinean population taken from the INDEC 2005. The figure shows that members of Assembly of Christ tend to have higher levels of formal education than their Protestant (and particularly Pentecostal) peers: only $36.6 \%$ of the interviewed members of AC state that they have not completed a secondary school degree versus the almost $80 \%$ of Protestants in the Conicet survey. With regard to the general distribution of educational degrees in the Argentinean society, AC members still show a higher average education: while $55.2 \%$ of the Argentinean population do not hold a secondary school degree, only $36.8 \%$ of the AC informants do not have a secondary school degree. Thus, on average, AC members not only

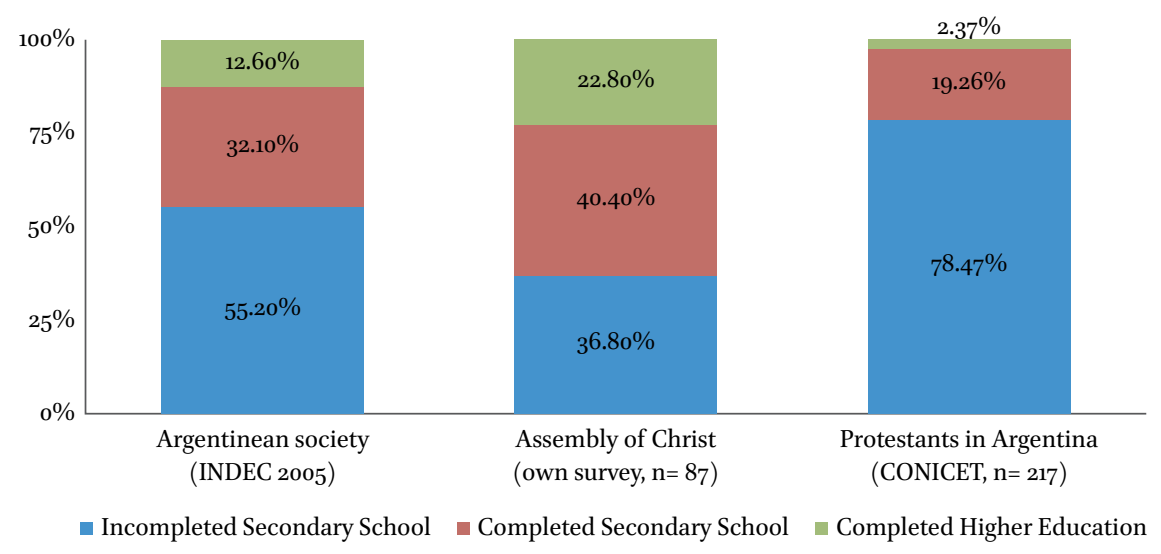

FIGURE 13 Level of education: Argentinean society, members of AC, and Protestants (OWN COMPOSITION BASED ON INDEC 2005, CONICET 2008, AND OWN SOURCE)

$38 \quad$ See Conicet 2008. 


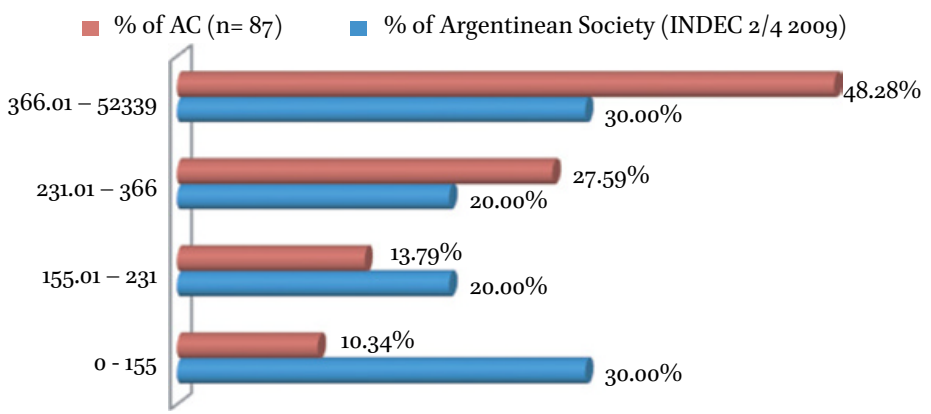

FIGURE 14 Household income per capita in Us-Dollars: AC and Argentinean Society (OWN COMPOSITION BASED ON INDEC 2015 AND OWN SOURCE)

hold higher educational degrees than their Protestants peers, but also than the average Argentinean.

Another indicator for the elevated social position of AC members is their economic income. Figure 14 compares the distribution of household income per capita among AC members with the distribution of household income per capita among the Argentinean population. The figure exhibits, for instance, that thirty percent of the Argentinean households have a household income per capita of less than $55^{2}$ Argentinean pesos per month, while only ten percent of the interviewed AC members have household incomes in this range. The other extreme is the group of those who perceive a household income above 1300 Argentinean pesos per capita. These are the better off among the Argentinean population. Almost fifty percent of AC members are from this group while this is true of only thirty percent of the total Argentinean population. ${ }^{39}$ Hence, higher income sectors are overrepresented while lower income sectors are underrepresented in AC. In other words: AC members are generally wealthier than the average Argentinean.

Occupations of Assembly Christ members are mixed: one can find some manual workers - like taxi drivers, mechanics, or butchers - and many professionals and independent business-men such as physicians, engineers, lawyers, managers, school and university teachers, merchants, and business owners.

39 One also can read the figure in a different way: only $10 \%$ come from the $30 \%$ of the Argentinean society who have a household income per capita of less than 155 Us-Dollars, while almost $50 \%$ of AC form part of the richest $30 \%$ of the Argentinean population. This part of the population has a household income per capita of more than 366 us-Dollars in 2009. When supposing that the $50 \%$ of the Argentinean society who perceive the highest incomes together form Argentina's middle class and upper class in terms of income, one can then conclude that almost $80 \%$ of AC members are from this group. 
The majority of members work in formal, well paid, white-collar occupations and are generally white and well educated.

In sum, the social composition of Assembly of Christ is not entirely homogenous but widely dominated by the middle class. In contrast to God Is Love its members are not situated on the margins of the society, but form the majority of the established middle class.

Pastors and members of AC do not ignore the fact that they are mainly a middle class church. Members define their church as a middle class Pentecostal congregation and are aware of the fact that the social composition of AC is exceptional for a Pentecostal congregation. With regard to the comparatively low proportion of lower class members, Pastor Victor mentions in an interview that the congregation may have a problem with attracting and binding lower class individuals. According to his observations, individuals from poor social backgrounds sometimes visit AC but do not end by affiliating with the congregation. After participating in one or two church services they do not come back. ${ }^{40}$

\subsubsection{Religious Practice}

The following description of AC's religious practices stresses the church service, as it forms the core of the collective religious practice in AC. ${ }^{41}$ The church service follows a general structure, beginning with a long praise (alabanza) which lasts at least half an hour and is intercepted by prayers and organizational announcements. It follows a more extensive prayer that is again followed by praise. Then, the service continues with tithing, accompanied by a prayer. Again, the congregation sings a song, and this leads to the main sermon, which will last between half an hour and an hour. After the sermon, the church service ends with a prayer and praise. Additionally, at the end, there is sometimes a call to the pulpit for those who want to pray for a specific concern. The whole church service has a duration of between two and a maximum of three hours. Praise and sermon are the most prevalent practices during the church service.

$40 \quad$ See Interview Pastor Victor Part 1.

41 Sunday church service is the collective practice that involves the highest proportion of members and that assumes the highest importance for members. Therefore, the church service is the practice that most characterizes the identity of AC. Besides the church services, there are also several church groups, as described above. According to Pastor Victor only $50 \%$ percent of church members participate in some way in church activities that are not related to the Sunday church service. The low involvement of many church members becomes particularly evident regarding the group for adult male members. Only around 10 male members are engaged in this group. 
Church services take place Wednesday evening, Saturday evening, and Sunday morning. The Wednesday evening is the smallest meeting, with only around fifty attendees. This meeting appears to be rather flexible and attendees are free to step forward to the pulpit to relate personal experiences, stories, or reflections. Saturday worships are normally organized by one of the church groups - the youth, the women, or the men group - and attract around one hundred participants. Here, each group can shape the service according to its preferences and style. The youth group, for instance, organizes between one and two Saturday services each month. These church services are inclined to Christian rock music and assume a slightly more emotional style than the "average" church service in Assembly of Christ. By contrast, the Sunday morning church service is the most important church meeting. Around three hundred members frequent this service each week. It starts officially at 10 am and ends generally between 12 am and 12:30 am.

The schedules for church services are fixed. They begin punctually with the praise section, during which most participants arrive. Members are dressed in different ways since there is no official doctrine with regard to physical appearance. Many members arrive in leisure sports cloth, shorts, and polo shirts and young women may even be dressed in close fitting dresses. Many of the elder women sport colored short hair. Still, a few members dress in a rather traditional and conservative way, wearing suits or in the case of women long dresses.

Arriving members are welcomed with a warm handshake or hug by church ushers and the main pastor in the entrance hall. After talking to ushers, a pastor, or other members, participants take a seat in the main hall and listen or sing to the praise music.

\subsubsection{Musical Praise}

The praise consists of different types of music depending on the church service. The church orchestras are equipped with well-trained musicians and several gifted singers who play a wide variety of styles from classical to Christian pop music. The orchestra generally consists of a singer and four background singers, a piano, drums, guitar, bass, violin, and at least one wind instrument (saxophone, trumpet). Due to the high quantity of musicians in AC, the composition of the orchestra or the whole orchestra may vary during the same church service. The musicians play Christian rock and pop-music, ballads, hymns, gospel, classical orchestral music, and even jazz pieces. From to time, one of the musicians also plays or sings a solo. However, the majority of songs are soft pop ballads and hymns. In comparison with other Pentecostal churches, the music 
is slower, rather quiet, and less overwhelming, though the musical quality is higher. The text of the songs frequently address God's Love and expresses adoration for God. The lyrics are projected on a wall above the pulpit, so every member can join and sing with the orchestra. The sound and video projections are arranged by two audiovisual engineers, who, situated in the upper part of the church, make use of sophisticated electronic equipment for their duties.

The musical praise is the most repeated and prevalent practice of church services. Aside from the beginning of the church service, praise is played several times during the worship and may therefore fill more than the half of the total duration of the church service.

Despite its large presence and importance for the church service, the audience acts comparatively quiet during the praise. Some participants may sing and clap their hands to the rhythm of the song, but many stand still and prefer not to join in the singing. In contrast to other Pentecostal churches, members show less physical and emotional involvement. They do not raise their hands up, move their bodies, or even dance to the songs.

\subsubsection{Praying and Tithing}

The prayer is another important religious practice. In smaller church services, particularly on Wednesdays, prayers assume a more interactive form. The member in charge of the prayer asks the audience for motives and contents for the following prayer. On these occasions, participants stand up and explain their requests to the audience. The most popular topic is health and in particular the healing from illness or disease. Other topics are, for instance, alcoholism, economic security, crime, finding the right way ("no apartarse"), receiving wisdom and strength, etc. In addition to the type of prayers that contain concrete requests of members, there is another, more general form of prayer, which is more prevalent and asks for more general "goods", like salvation, forgiveness, or wisdom and expresses gratitude by worshipping God. Both types of prayer assume a quiet and contemplative form. The praying individual speaks quietly and does not shout while the audience stands and inclines their heads. Some may raise an arm during the prayer. But none of the participants prays loudly, trembles, or yells during the prayer.

Offering and tithing are carried out before the sermon and take place only once during a church service. Although offering and tithing are financially important for the organization, they play a minor role. A member at the pulpit asks the congregation for their offerings. Then, ushers pass between the seat rows to collect the offering, while a member at the pulpit says a prayer. After this, the church service continues with a song. 


\subsubsection{The Sermon}

At the heart of every AC church service lays the sermon which is regarded as the most important practice of the service. ${ }^{42}$ Besides the main sermon, there may be one or two shorter, sermon-like contributions during the same service. Members are highly involved in the preaching. They may conduct shorter sermons or even the main sermons in the Wednesday and Saturday service. The main sermons on Sundays are, however, normally reserved to the main pastor or an invited guest preacher. The style of preaching is comparatively calm. Preachers may emphasize parts of their sermon by speaking more resolutely and raising their voice, but they do not shout or yell. Furthermore, preachers do not ask members to perform particular corporal practices, like raising their hands up or putting them on their head during the sermon.

The sermon consists normally of an exegesis of a passage of the Bible and its reconnection to daily life. The preacher reads or refers to a longer part of the Bible and interprets it. Sometimes preachers may even raise different interpretations and approaches, and compare them with each other in order to identify the most appropriate interpretation.

Finally, the preacher brings the Bible narrative back into the context of daily life by addressing a problem of the society as a whole or a challenge in the daily life of modern individuals (suffering, sin etc.). Frequently, the preacher relates these topics to the general question of real Christian faith. When applying the message of the Bible, preachers often indicate how Christians can deal with their problems or act morally in the context of modern society.

The sermons are realized in an accentless, white collar Spanish. The elaborate, often pompous, way of communicating makes the sermons sometimes resemble a university lecture. The frequent application of metaphors and a theological way of interpreting the Bible and its argumentation contribute to this impression. The pastors call this style of preaching predicación expositiva (expositive preaching). They stress that "expositive preaching" is a key factor for the identity and success of the church and distinguishes it from the oldfashioned, spiritual Pentecostalism that emphasized the experience of the Holy Spirit. Instead of the experience, the intellectual comprehension of the Bible stands at the center of the religious practice. ${ }^{43}$

Sermons address different topics: troubles of Argentina or the world; spiritual and moral growth; the criticism of other churches; the moral obligation of

42 See Interview Pastor Nicolás; Interview Pastor Victor Part 1.

43 See Interview Pastor Nicolás; Interview Pastor Victor Part 1. 
being a role model to the society and to contribute to its improvement; the moral purification of one's life; obtaining wisdom; the afterlife; and last but not least, the real Christian faith. In addition to these over-arching themes, preachers frequently refer to the current society and its problems. Typical issues that are addressed are insecurity and crime, social inequality and poverty, the disruption of the ecological system, and the crisis of the economy. Society is critiqued for its egoism and lack of faith. Real Christians are expected to distinguish themselves from society, and to involve themselves at the same time in the society in order to transform it. This transformation plays an important role in the church's discourse, where the church wants to assume an active role in the transformation of the society and "hacer historia" ("make history"), as the preachers claim. Subsequently, members are asked to engage themselves actively in the transformation process of the society through social projects and donations: the love for God should not only express itself in the praise for Him, but also in the moral behavior of the individual, particularly loving and helping needy others.

In contrast to God Is Love, evil forces and their impact on the empirical reality of daily life are not a topic of religious discourse. Satan and demons are not mentioned in the sermons. Only on a few occasions, did I hear references to miracles or divine interventions in the daily life of members. Due to this lack of references to supernatural action, sermons appear to be more secular than that of God Is Love and other Pentecostal churches. ${ }^{44}$

A striking moment that appears from time to time in the sermons is the criticism of other styles of Pentecostalism. In one of his sermons, the pastor of AC criticizes, for example, that many Pentecostals pursue easy and fast solutions for their daily problems in Pentecostal churches. According to the pastor, they tend towards religious fetishism and a secular gospel and their only concern is to escape the suffering. ${ }^{45}$ Such a secular gospel is described as limited to the daily, empirical world and as not reaching out to the afterlife. ${ }^{46}$ This accusation of religious pragmatism is a frequent critique against other Pentecostals. Miracles and this worldly improvement are not regarded as a legitimate objective of one's religious practice. Instead the afterlife is seen as the principle aim of religious practice and belief. ${ }^{47}$

44 However, the possibility of divine healing and supernatural forces acting in the human sphere would not necessarily be denied by church members.

45 This is an allusion to the IURD and their phrase "Paré de sufrir!".

46 Instead, the real believer is thought to focus on what follows after the secular existence: eternity. See church service 3rd May 2009.

47 Interview Pastor Victor Part 2. 
Other criticisms center on the prosperity gospel and idolatry in the Pentecostal movement. Prosperity gospel is seen as a false doctrine that stresses superficial materialism and distracts the believer from the important objectives (topics) of faith. This criticism goes hand in hand with denouncing Pentecostal pastors as "false prophets" who lie to their members and exploit them while preaching secular wealth. Pastor Victor states with regard to prosperity gospel:

The issue of prosperity, aren't we getting off track? Aren't we changing the purpose? Is it the Church's goal that a brother should get a new car, or give 100 pesos and get one hundred times more? Is this the message of the harvest - that you plant 100 pesos and you get 10,00o back? We're missing the point. That's why I say this. But I think that our church in Argentina is hurt - I'm not saying it's dead, because I trust in God. But we are not experiencing a revival here, or anything like it. And you read the books that come from the United States about a revival in Argentina, but it never really happened. There has never been a revival in Argentina, never ever. What we saw was a church that grew and then that was able very successfully to sell a product.

INTERVIEW PASTOR VICTOR PART 1

The distinction from other styles of Pentecostalism that are experienced as wrong or inappropriate, plays an important role for the identity of Assembly of Christ. ${ }^{48}$ Many of the criticisms raised by AC could be intuitively directed against God Is Love, since they concern a religious style that is practiced in GIL. God Is Love fits into the bogeyman image of the AC discourse. The AC discourse refuses a religious practice centered on the improvement of the daily life. Regarding its criticism of the earthly orientated Pentecostalism, one may conclude that the only concern of Assembly of Christ is moral purification and the afterlife. This is, however, not the case. Despite the importance that the AC discourse assigns to the afterlife and eternity, daily life also assumes an important position in AC's religious practice and beliefs. As previously mentioned, members pray for daily causes (e.g. illness). Moreover, they seek to contribute directly to the transformation of the world. They do not withdraw from society and accept their fate waiting for the end to come. Instead, they want to shape the society.

48 His critical position with regard to other Pentecostal churches raises the question of why the main pastor officially represents Pentecostalism as a head of an umbrella organization like FECEP. The contradiction between his opinions about other Pentecostal churches and his position in the field is partially undermined by the fact that the umbrella organization he represents is particularly bound to the middle class, as will be shown below. 
Thus, their attitude seems to be ambivalent: while they emphasize salvation and afterlife as the principle objective of their religion, their practice does not only center on the afterlife. It includes also the search for an improvement of daily life through social action and religious practices.

In any case, AC members comprehend their religious practice as less orientated towards the improvement of daily life and less pragmatic than the practice of other Pentecostals. According to their religious discourse, eternity and the unconditional love for God should be the essential cause of Pentecostal practice and belief, instead of earthly concerns. ${ }^{49}$

\subsubsection{Spiritual Practices and Expressivity}

The religious practice during the church service is shaped by oral discourses such as sermons - rather than by physical and emotional involvement. There are no exorcisms; preachers do not ask the audience to perform specific physical movements or to repeat phrases; nor do participants speak loudly in tongues, dance or tremble in the Spirit. Moreover, religious practices that include objects, such as the blessing of items, are totally absent. Members do not bring cloth, photos, keys, or bottles of water to the pastor to bless them, as these practices are regarded as fetishism. ${ }^{50}$

The only religious practice that integrates the body in a more significant way is a specific prayer, which occasionally takes place at the end of church services. Members who want to pray for particular causes in a more concerted way can step forward to the pulpit. Here, they will kneel down and pray while the orchestra plays calming music. Meanwhile, pastors and selected ushers pass through the line of kneeling members, speak to them, lay hands on their shoulder, and display affection. The atmosphere remains calm and any kind of emotional outburst is absent. Sometimes some of the kneeling members cry quietly and receive hugs from the pastor or ushers. This is the most emotional and corporal practice in AC; however, it involves only a very small part of the congregation. ${ }^{51}$

Typical manifestations of the Holy Spirit which one can often observe in Pentecostal churches such as faith healing, exorcisms, and miracles are absent in AC. In none of my visits did I observe an exorcism, faith-healing, or any similar practice. Nevertheless, AC's pastors inform me that cases of individuals

\footnotetext{
49 See Interview Pastor Victor Part 2. See also Kravetes 2008: 101.

5o Interview Pastor Victor Part 2.

51 Pastor Victor described this prayer as different from the practice of laying on hands on the forehead and the blessing with oil, which is very rare in AC. See Interview Pastor Victor Part 2.
} 
appearing to be demonized were not totally absent. However, pastors stated that they would not perform exorcisms in front of the whole congregation. In the very rare occasions of someone acting "strange," the pastor and ushers would take the person aside to a more private space in the church. Here, they would seek a dialogue and try to calm the person down. According to Pastor Victor, only in very few cases, individuals are actually possessed and need more spiritual attention. ${ }^{52}$

Expressions of physical and emotional involvement are hardly visible in AC. On no occasion did I observe people dropping to the ground, tumbling in ecstasy, or crying out loudly; nor was there the subsequent shouting of "Gloria a Dios!" or similar exclamations. Participants show far less emotional and physical engagement than those of God Is Love. During the songs, many participants are reluctant to sing and clap their hands and, in many cases, they appear to limit and control their physical expression.

Only very few members show an emotional involvement or speak quietly in tongues. The few members who showed more involvement - such as raising hands during the praise - were from lower class backgrounds. Interestingly, two lower class AC members explained during narrative interviews that they liked more expressive styles. In contrast to middle class interviewees from AC, they showed no rejection of exorcisms and strong spiritual manifestations during church services and even claimed that it would be favorable for the congregation to integrate these practices into the church service. ${ }^{53}$

Glossolalia forms are a controversial topic in $\mathrm{AC}$, and pastors are generally critical of its practice during the church service. Pastor Victor, for instance, argues harshly against it: in cases of participants sticking out by speaking loudly in tongues, he would take them aside after the service, and recommend them to stay quiet if there is no translation. Speaking in tongues and other strong comportments that can be interpreted as emotional are regarded as a disturbance. ${ }^{54}$ The following statement from the pastor demonstrates how practices such as faith healing, testimonies, and glossolalia are viewed in AC:

How does God feel when you write "Miracles and Healing meeting today" on a sign? What if God doesn't want to heal today? Who are you to say that today God is going to heal? Is God not sovereign? God heals when

$5^{2}$ In his whole career as a pastor, Pastor Victor remembers having seen only three severe cases, in which the individuals were probably possessed. See Interview Pastor Victor Part 2; Interview Pastor Nicolás.

53 See Interview Simón Part 2; Interview Andrés.

54 See Interview Pastor Nicolás. 
He wants to, and when He doesn't want to, He doesn't heal. A lot of the testimonies people give are false, and some of the testimonies that say "I walked, I walked, I walked," is just adrenaline. I've seen it. Later, that same woman has the same problem. How much of the healing that occurs is documented by doctors? Why is that? Because you put your own attitude into these experiences. God never said that. He told us to go forth and preach the Gospel, and those who believe will see the signs. I am not saying that God does not heal. If I get sick, the first thing that I'm going to do is to ask God to heal me. But our testimony should not be focused on that. Jesus said that disbelievers demand a sign. So when the church service is based on that, we are getting it wrong (...). Why at church do people scream in tongues, 20 or 30 people speaking in tongues at the same time? When that happens here, where we usually have one or two, we try to take them aside at the end of the service and tell them, "Brother, if you see that there is no practical interpretation, please don't speak." Because they are focused on the experience. And falling down - why does God need us to throw ourselves to the ground? I think these are religious practices that take away from the true purpose of a service, which is worshipping God, preaching the Word, and breaking bread.

INTERVIEW PASTOR VICTOR PART 1

This statement emphasizes the position of the church with regard to manifestations of the Holy Spirit and more specifically concerning glossolalia. Speaking in tongues and other spiritual manifestation are not welcomed in the context of the church service. Interestingly, however, some members mentioned to me that they would speak sometimes in tongues at home while they refused to do so in the public sphere of church services. ${ }^{55}$

\subsubsection{Towards a Socially More Adapted Style of Pentecostalism}

The religious practice of AC does not include any significant manifestation of the Holy Spirit and appears to be barely Pentecostal. Nevertheless, pastors and members believe in the Holy Spirit and its gifts. That is to say, they do not neglect the possibility of miracles and divine healing, and supernatural interventions in daily life are regarded as possible. ${ }^{56}$ Thus, they do not differ from other Pentecostal and charismatic congregations when it comes to the religious

55 See, for instance, Interview Luis.

56 See Interview Pastor Nicolás; Interview Pastor Victor Part 1, Interview Simón; Interview Luis; Interview Laura; Interview Isabela. 
belief in the Holy Spirit. ${ }^{57}$ At the same time, there is little emphasis on practices that involve the supernatural, including the gifts of the Holy Spirit - like faith-healing, exorcism, speaking in tongues, the blessing of items or prophecy. Instead of the gifts of the Holy Spirit, other practices are emphasized, like the sermon, the teaching and interpretation of the Bible, and the praise. Pastor Victor argues that the most prevalent gifts of the Holy Spirit in AC are the gifts of preaching, teaching, and science. ${ }^{58}$ Consequently, Assembly of Christ is marked by oral and intellectual rather than corporal and emotional practices. The official discourse and practice of Assembly of Christ is notably more secular than God is Love and situates it in proximity to the practice of traditional Protestant churches.

In total, AC represents a controlled, softly charismatic and socially more acceptable type of Pentecostalism. Although being socially more adapted, non-Pentecostal middle class Argentineans may still perceive the church and its practices as strange. One example for the remaining tension between what is experienced as appropriate by the middle class and AC's religious style are Alberto's first experiences in AC. Alberto converted in AC to Pentecostalism. Before his conversion, he was a nominal Catholic who grew up in a middle class family in Devoto. His "conversion career"59 started when his new girlfriend, a member of AC, invited him to AC's church services. Visiting AC the first time, Alberto experienced its religious practice as strange ("loco") and could not stand to stay during the whole time of the church service. However, encouraged by his girlfriend, he stayed a bit longer each time and finally converted to Pentecostalism. Another example for the remaining deviations from the middle class representations is the fear of embarrassment in sharing one's faith: Laura, for instance, chose AC because she felt that this church would offer lower chances of feeling embarrassed when bringing friends to its services, but she is still afraid of fellow members behaving inappropriately. ${ }^{60}$

Hence, despite being more socially adapted than GIL, AC appears to still represent a deviation from what is regarded as appropriate. Nevertheless, middle class interviewees who were not members of AC were very open to the videos I showed them from the church. The fact that it represents a more appropriate and adapted form of Pentecostalism seems to explain AC's social

However, Pastor Victor seems to be skeptical regarding the degree of supernatural involvement in daily reality: miracles do not occur always and everywhere, and it is not prudent to rely on their occurrence. Interview Pastor Victor Part 2.

59 Gooren 2005, 2007.

6o Interview Laura. 
composition. It provides a type of Pentecostalism that is experienced as more appropriate by the middle class and is, therefore, able to recruit its members from this social segment.

\subsection{Comparing the Social Composition and Religious Styles of GIL and AC}

The previous sections of this chapter have described the two churches God Is Love and Assembly of Christ. In these descriptions it became evident that each church mainly attracts a specific social class and demonstrates a particular religious style. However, these churches have, so far, not been directly compared. Therefore, this section compares the social composition and the religious styles of both churches. The comparison of their styles illustrates the boundary work of AC.

AC and GIL recruit the majority of their members from different social classes. The class differences between the memberships of both churches become clear when comparing the education and income of members. Figure 15 compares the data from GIL and AC with general data about the educational composition of the Argentinean society and the educational composition of Protestants in Argentina.

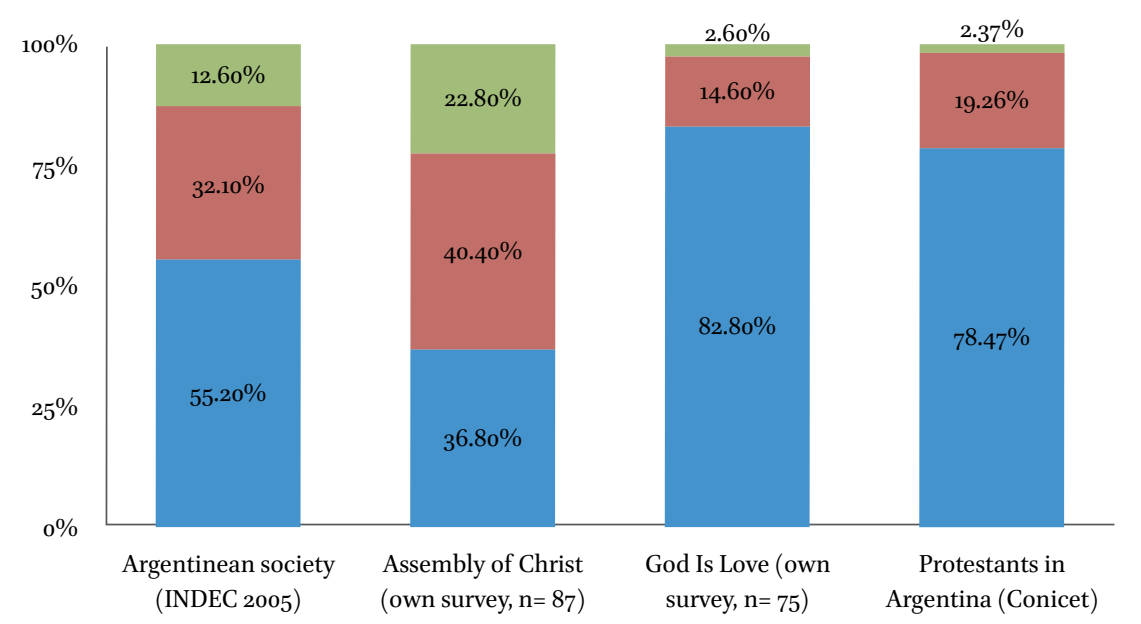

Incompleted Secondary School $\square$ Completed Secondary School $\square$ Completed Higher Education

FIGURE 15 Education: Argentinean society, AC, GIL, and Protestants in Argentina (OWN COMPOSITION BASED ON INDEC 2005, CONICET 2008, AND OWN SOURCE) 
The first row shows the educational distribution of the Argentinean society, while the last row shows educational distribution of Protestants. The two rows in the middle exhibit the educational distribution of AC and GIL interviewees. The general differences in the educational distribution between Protestants and Argentinean society were previously discussed. What is of interest here is that the educational distribution of GIL closely resembles that of Argentinean Protestants in general, whereas it shows significant differences to the educational distribution of Argentinean society and even stronger differences to AC. With respect to its educational distribution, GIL can be treated, to some extent, as a typical case of Protestantism, showing levels of formal education that are significantly below the average Argentinean. Regarding AC, it is striking that the educational distribution is not only exceptional for Protestants, but even with regards to the Argentinean society: the average formal education of AC members is still considerably higher than that of Argentinean society. One can determine substantial differences between both churches, not only in the educational distribution of both churches, but also in the distribution of incomes. Figure 16 compares the distribution of household income per capita between AC, GIL and the Argentinean society in the second quarter of 2009:

Here also, the differences between both churches are more than apparent. Almost half of the AC interviewees (48.28\%) are among the wealthiest $30 \%$ of the Argentinean population, while only $6.67 \%$ of GIL interviewees are from this group. In contrast, $60 \%$ of GIL interviewees are from the $30 \%$ of the Argentinean population with the lowest household income per capita, whereas

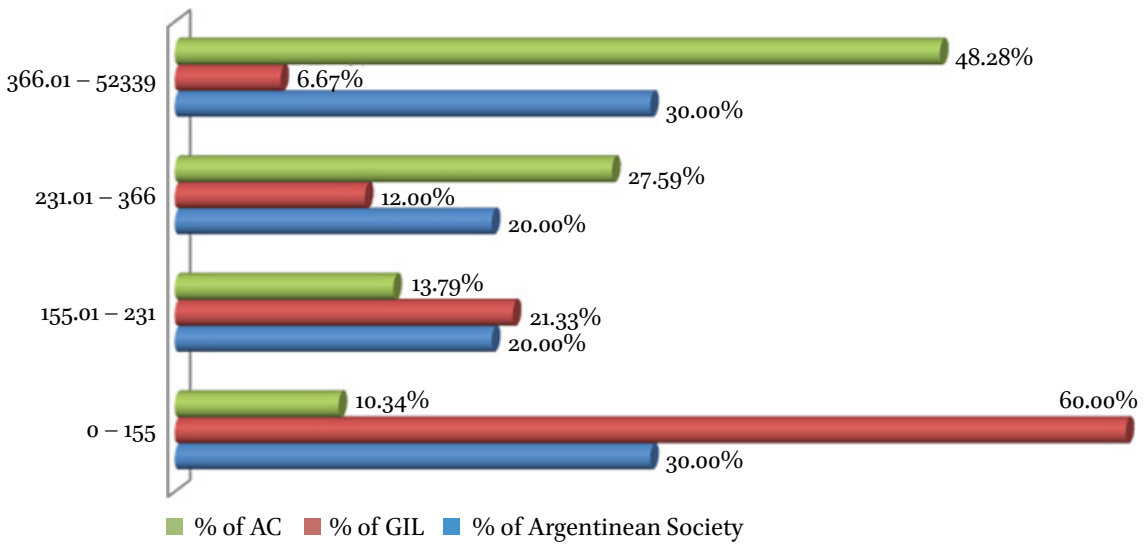

FIGURE 16 Household income per capita in US-Dollars: AC, GIL, and Argentinean Society (OWN COMPOSITION BASED ON INDEC 2015 AND OWN SOURCE) 
only $10.24 \%$ of AC interviewees are from this group. This comparison not only shows that both churches recruit the main part of their members from different income strata, but also that the income composition of both churches differs significantly from that of Argentinean society in general. AC tends to recruit its members from social strata with household incomes per capita that are above the Argentinean average, while GIL recruits its members mainly from social strata with household incomes per capita that are below the Argentinean average.

The description of GIL and AC has already revealed that the religious style of both churches substantially differs: despite the fact that both churches are Pentecostal and share the same Pentecostal beliefs, they show significant differences in their infrastructure, organization, symbolical recognition, religious practices, and discourses. These differences are related to different types of symbolic boundaries.

First, both churches differ considerably in their infrastructure and organization. These differences can be described as structural and organizational boundaries. AC cultivates its distinctiveness by developing a more sophisticated organization and infrastructure than other Pentecostal churches.

Furthermore, the two churches also show differences with regard to their integration into the formal circle of evangelical Protestantism and their symbolic recognition. AC is deeply integrated in the formal circle of evangelical churches in Argentina. By contrast, GIL is not affiliated with any of the umbrella organizations of Argentinean Protestantism nor is it integrated in any way into the formal circle of evangelicals. Additionally, Pentecostal churches with a Brazilian background like GIL tend to be perceived critically. ${ }^{61}$ Regarded from the viewpoint of the formal circle of evangelical Protestantism, the symbolic recognition of GIL is low. One can speak of "legitimate" boundaries, meaning boundaries that are drawn on the basis of legitimacy and symbolic recognition.

Besides these differences, there are also similarities. Both churches define themselves as Pentecostal. Members and pastors of both believe in the gifts of the Holy Spirit: they believe in miracles, the gift of tongues, prophecy, faithhealing, and exorcisms. Although both churches are Pentecostal and seem to share basic beliefs of Pentecostalism, they show significant differences in their

$61 \quad$ Evangelical churches with a Brazilian background like GIL suffer from being confounded with IURD or classified in the same categories as IURD. Thus, they are often regarded among the Argentinean population and evangelicals as money-making businesses which exploit their members by providing questionable spiritual services. 
religious practice which become evident in the style of their church services. Remarkable differences conern the style of the musical praise and the involvement of spiritual practices. Spiritual practices such as faith-healing, exorcisms, prophecy, laying on of hands, and speaking loudly in tongues are ubiquitous in God Is Love, but widely absent in AC. Moreover, the style in which spiritual practices are performed also exhibits major differences. The religious practice in GIL is expressive, involves the body, and seeks improvements in daily life. Its discourses circle around demons, miracles, and supernatural interventions. In $\mathrm{AC}$, these characteristics are almost or totally absent. The religious practice of AC is less expressive than in GIL: members do not speak loudly in tongues, raise their arms, or shout out. The atmosphere stays quiet and sober. Physical expressions and emotions are restricted to a degree that is experienced as appropriate. The body is widely excluded from the congregational practice, and instead the intellect is emphasized. The differences in the practice of both churches point to the drawing of expressive boundaries.

AC rejects religious pragmatism, which its pastors believe to witness in other Pentecostal churches. Instead of spiritual intervention practices and rituals, AC relies on an oral intellectual discourse that culminates in the sermon, which consists of an intellectual interpretation of passages from the Bible. As such, AC's sermons often stress problems of the (post)modern society and the duty of moral purification. But unlike GIL, AC does not try to enforce moral purification on its members by establishing harsh rules of conduct. Instead, AC relies on the autonomy and inner control of the individual. For these reasons, AC seems to apply "soft" strategies such as acculturation and education. Thus, education and (intellectual, spiritual and personal) development are emphasized in AC. GIL, in contrast, does not stress education and intellectual development. These differences point to educational and moral boundaries. AC draws symbolic boundaries by stressing education and personal development and emphasizing a morality that is different from the alleged pragmatism of lower classes.

In total, AC's style represents a softened and "rationalized" Pentecostalism. The congregation knows that AC's style is different from the majority of Pentecostal churches and cultivates these differences. Pastors proudly emphasize the distinction of AC from other Pentecostal churches while criticizing "mass Pentecostalism" for being fake and superficial. The fact that harsh criticism is directed against Pentecostal styles that resemble those of GIL illustrates the boundary work of AC and the contrast between both churches. GIL and AC represent two different styles of Argentinean Pentecostalism. The style of GIL widely corresponds to Latin American popular culture and religion. AC, by contrast, seeks to distinguish itself from popular religion by drawing upon 
different types of symbolic boundaries and developing a softened, more socially adapted style of Pentecostalism.

\subsection{Summary}

The objective of this chapter was to study the example of two Pentecostal churches: God Is Love (GIL) and Assembly of Christ (AC). The analysis of these churches provided detailed insights that illustrate the boundary work of Pentecostal churches. The two churches described in this chapter attract different social sectors and represent highly contrasting styles of Pentecostalism.

GIL predominantly attracts the lower class. Its religious style emphasizes characteristics that are often associated with Pentecostalism, such as spiritual intervention practices, an expressive and emotional atmosphere, a mostly under-developed infrastructure and organization, and a spiritual focus on the improvement of daily life. This style of religion does not fit well with middle class representations of appropriateness. Many of the practices of GIL, such as exorcisms and speaking loudly in tongues, appear inappropriate or even shocking to the middle class. Therefore, middle class Pentecostals are likely to draw boundaries in opposition to this type of Pentecostalism.

$\mathrm{AC}$, which predominantly attracts the middle class, distinguishes itself from this style of Pentecostalism by drawing upon several types of boundaries. AC abstains from many practices involving the Holy Spirit, such as exorcisms, faith healing, and speaking in tongues. Despite believing in the gifts of the Holy Spirit and the possibility of supernatural intervention in daily life, the gifts of the Spirit are not as present as in other Pentecostal churches. Physical manifestations and experiences are rare. At the same time, the atmosphere is less expressive and appears to be more controlled than in other Pentecostal churches. Being bound to the representations of the middle class, these middle class Pentecostals cannot accept Pentecostalism in its "inappropriate" form. In order to feel more comfortable with their religious affiliation, they adapt Pentecostalism to their class representations. They "civilize" Pentecostalism by developing a specific style that draws boundaries in opposition to the "inappropriate" characteristics of Pentecostalism.

Based on the empirical findings, one can distinguish five types of boundaries employed to mark a difference: structural and organizational boundaries, legitimacy boundaries, expressive boundaries, educational boundaries, and moral boundaries. Drawing upon these boundaries, AC develops a more socially adapted and softly charismatic style that distinguishes itself from GIL 
and many other Pentecostal churches. Representing a religious style more acceptable to the middle class, middle class actors are more likely to affiliate themselves with this type of Pentecostalism than with a GIL-like style of Pentecostalism.

This study has so far only considered the Pentecostal styles of two churches. Other lower and middle class congregations may exhibit different characteristics. For this reason, more Pentecostal churches will be introduced in the analysis of the following chapter. 